Review Article

\title{
Plant Natural Compounds in the Treatment of Adrenocortical Tumors
}

\author{
Jacopo Manso $\mathbb{D D}^{1}{ }^{1}$ Javad Sharifi-Rad $\mathbb{D}^{2,3}$ Wissam Zam ${ }^{20},{ }^{4}$ Patrick Valere Tsouh Fokou (iD), \\ Miquel Martorell ${ }^{(D)}{ }^{6,7}$ and Raffaele Pezzani ${ }^{10}{ }^{1,8}$
}

\author{
${ }^{1}$ Endocrinology Unit, Department of Medicine (DIMED), University of Padova, Via Ospedale 105, Padova 35128, Italy \\ ${ }^{2}$ Phytochemistry Research Center, Shahid Beheshti University of Medical Sciences, Tehran, Iran \\ ${ }^{3}$ Facultad de Medicina, Universidad del Azuay, Cuenca, Ecuador \\ ${ }^{4}$ Analytical and Food Chemistry Department, Faculty of Pharmacy, Tartous University, Tartous, Syria \\ ${ }^{5}$ Faculty of Science, University of Bamenda, Bamenda-Bambili, Po. Box 39, Cameroon \\ ${ }^{6}$ Department of Nutrition and Dietetics, Faculty of Pharmacy, Centre for Healthy Living, University of Concepción, \\ Concepción 4070386, Chile \\ ${ }^{7}$ Universidad de Concepción, Unidad de Desarrollo Tecnológico, UDT, Concepción 4070386, Chile \\ ${ }^{8}$ Phytotherapy Lab, Endocrinology Unit, Department of Medicine (DIMED), University of Padova, via Ospedale 105, \\ 35128 Padova, Italy
}

Correspondence should be addressed to Jacopo Manso; jacopo.manso@gmail.com and Raffaele Pezzani; raffaele.pezzani@unipd.it Received 9 January 2021; Revised 14 May 2021; Accepted 31 August 2021; Published 17 September 2021

Academic Editor: Ma gorzata Kotula Balak

Copyright $\odot 2021$ Jacopo Manso et al. This is an open access article distributed under the Creative Commons Attribution License,
which permits unrestricted use, distribution, and reproduction in any medium, provided the original work is properly cited.

Plant natural products are a plethora of diverse and complex molecules produced by the plant secondary metabolism. Among these, many can reserve beneficial or curative properties when employed to treat human diseases. Even in cancer, they can be successfully used and indeed numerous phytochemicals exert antineoplastic activity. The most common molecules derived from plants and used in the fight against cancer are polyphenols, i.e., quercetin, genistein, resveratrol, curcumin, etc. Despite valuable data especially in preclinical models on such compounds, few of them are currently used in the medical practice. Also, in adrenocortical tumors (ACT), phytochemicals are scarcely or not at all used. This work summarizes the available research on phytochemicals used against ACT and adrenocortical cancer, a very rare disease with poor prognosis and high metastatic potential, and wants to contribute to stimulate preclinical and clinical research to find new therapeutic strategies among the overabundance of biomolecules produced by the plant kingdom.

\section{Introduction}

The use of plants and plant-derived compounds dates back to prehistory. Prehistoric humans probably learned the beneficial use of plant natural substances from animals and over the years; they refined the curative technique applying new preparative methods (drying, boiling, concentration, collection period, etc.) in addition to the simple ingestion of fresh plants. Even at the present day, plants remain a wide and valuable source of natural compounds that can sometime become new therapeutic tools or even drugs, given the extensive range of diversity of phytochemical structures [1]. Plant natural products play a key role in different human diseases, including cancer. There are numerous research studies that reported the efficacy and safety of phytochemicals and about one-quarter of drugs derive from the plant kingdom [2, 3]. Moreover the first anticancer drugs used in clinics were alkaloids from Taxus baccata L. and Vinca spp. [4], two well-known plants for their therapeutic properties. Now such drugs are used to treat numerous tumors worldwide and represent an appreciated tool in the fight against cancer $[5,6]$. Also endocrine neoplasms as adrenocortical tumors (ACT) and, in particular, the rare and lethal adrenocortical cancer (ACC) can be a potential target for plant natural compounds. The aim of this review is to recapitulate available research on phytochemicals used against ACT and 
ACC, searching for different databases, such as Embase, Google Scholar, Ovid, PubMed, SciFinder, Science Direct, Scopus, and Web of Science. The search strategy was based on the combination of different keywords, such as phytochemical (main categories, carotenoids, nitrogen-containing compounds, organosulfur, alkaloids, phenolic acids, flavonoids), plant natural compounds, adrenal, tumor, adrenocortical tumor, and adrenocortical cancer/carcinoma. Only articles in English language have been selected, excluding patents and symposium or congress papers.

\section{Adrenocortical Tumors}

Adrenocortical tumors (ACT) are adrenal masses of different sizes, mainly benign in nature and discovered incidentally (so-called "incidentaloma") or due to signs and symptoms of hormonal secretion or compression. The prevalent etiology of adrenocortical tumors is nonfunctioning adrenocortical adenomas, which accounts for about $80 \%$ of cases [7]. Nonetheless, every patient should undergo a careful and comprehensive evaluation in order to identify hormone-secreting tumors (e.g., cortisol-secreting, aldosterone-secreting, or catecholamine-secreting tumors) or malignant tumors (e.g., adrenocortical carcinoma or metastatic adrenal cancer), which require surgery or medical treatment. Figure 1 summarizes available data on ACT.

2.1. Imaging. The prevalence of adrenal nodules is between 4 and $10 \%$ on computed tomography (CT) series depending on age $[8,9]$. In addition to the detection of adrenal lesions, imaging techniques are essential for distinguishing benign from malignant masses. Unenhanced CT is the most valuable imaging technique. In fact, it allows recognize benign lesions through the evaluation of tissue density measured in Hounsfield units (HU). Generally, an adrenocortical tumor with an $\mathrm{HU}$ of $\leq 10$ is a lipid-rich tissue and thus considered benign [10]. Contrast-enhanced CT is useful for the evaluation of washout in indeterminate adrenal tumors. Malignant tumors enhance rapidly but have a slower washout of contrast medium; consequently an absolute washout of $>60 \%$ in the medium phase strongly suggests a benign adenoma $[11,12]$.

Magnetic resonance imaging (MRI) has the advantage to avoid radiation exposure. The MRI technique of chemical shift is most commonly used to discriminate the benign masses from the malignant ones: the loss of signal on opposed phase imaging is indicative of an adrenal benign adenoma $[13,14]$.

Positron emission tomography with 18F-2-deoxy-dglucose (18-FDG PET) predominantly combined with CT is mainly used for the detection of malignant tumors, which shows increased glucose metabolism $[15,16]$.

The lesion size is a well-known predictor of malignancy. The $4 \mathrm{~cm}$ cutoff is generally adopted also in the latest guidelines, with a sensitivity of about $93 \%$ for malignancy, but with a poor specificity of $42 \%$ [7, 17]. Indeed, the guidelines recommend surgery for adrenal tumors $>4 \mathrm{~cm}$, mainly due to the extremely poor prognosis and highly aggressive nature of ACC [18].
2.2. Cortisol-Secreting Tumors. Cortisol-secreting tumors are responsible for the clinical scenario of Cushing's syndrome. About 5-20\% of all incidentalomas have some degree of autonomous cortisol secretion [19]. The symptoms and signs of exaggerated cortisol action are muscle wasting, relatively thin limbs, ecchymoses, thin skin, poor wound healing, striae (purple or "violaceous" rather than white), thin (osteoporotic) bones that easily fracture, diabetes mellitus, central obesity, rounded ("moon") face, "buffalo hump," susceptibility to infection, predisposition to gastric ulcer, hypertension, disturbance of menstrual cycle, symptoms overlapping with polycystic ovarian syndrome, and mood disturbance (depression, psychosis) [20]. There are three tests to screen for hypercortisolism: 24-hour urinary free cortisol test, late-night salivary cortisol test, and $1 \mathrm{mg}$ overnight dexamethasone suppression test. The last one is the recommended test for all adrenocortical tumors [18]. Serum cortisol levels post dexamethasone $\leq 50 \mathrm{nmol} / \mathrm{L}$ without cortisol-related comorbidities exclude autonomous cortisol secretion $[18,21]$. Serum cortisol levels post dexamethasone between 51 and $138 \mathrm{nmol} / \mathrm{L}$ should be considered "possible autonomous cortisol secretion" (previously known as subclinical hypercortisolism) and $>138 \mathrm{nmol} / \mathrm{L}$ indicate "autonomous cortisol secretion" (or overt hypercortisolism) $[18,22]$. However, there are a lot of conditions or drugs that can affect the results of the suppression test, e.g., estrogen therapies or malabsorption disease [23]. 24-hour urinary free cortisol and late-night salivary cortisol tests are useful in the doubtful cases or as confirmatory tests of hypercortisolism. The presence of an overt hypercortisolism is always an indication for adrenalectomy. Laparoscopic surgery versus open adrenalectomy is still debated; nevertheless, recent guidelines suggest (a) laparoscopic surgery in patients with unilateral adrenal tumor with radiological findings suspicious of malignancy and a diameter of $\leq 6 \mathrm{~cm}$ but without evidence of local invasion and (b) open procedure if there are also signs of local invasion [18]. If surgery is not feasible, pharmacological treatment for cortisol excess is available and can also be used before surgery to ameliorate the outcome [24].

2.3. Aldosterone-Secreting Tumors. Aldosterone-secreting adenomas represent between 1 and 3\% of all adrenal incidentalomas. Aldosterone-secreting tumors cause the so-called "Conn's syndrome" or primary hyperaldosteronism, which is characterized by resistant hypertension and hypokalemia with an abnormal aldosterone/renin ratio [19]. Due to the low rate of aldosterone secretion, recent guidelines recommend the use of aldosterone/renin ratio to exclude primary aldosteronism only in patients with adrenal tumors and concomitant hypertension or unexplained hypokalemia [7]. When testing the aldosterone/renin ratio, potassium should be adequately corrected and drugs that can interfere with aldosterone and renin levels (e.g., aldosterone antagonists) should be avoided [25]. In case of abnormal aldosterone/renin ratios, patients should undergo at least one confirmatory test. When feasible, adrenalectomy is the gold standard; otherwise medical treatment with aldosterone antagonists should be initiated in 


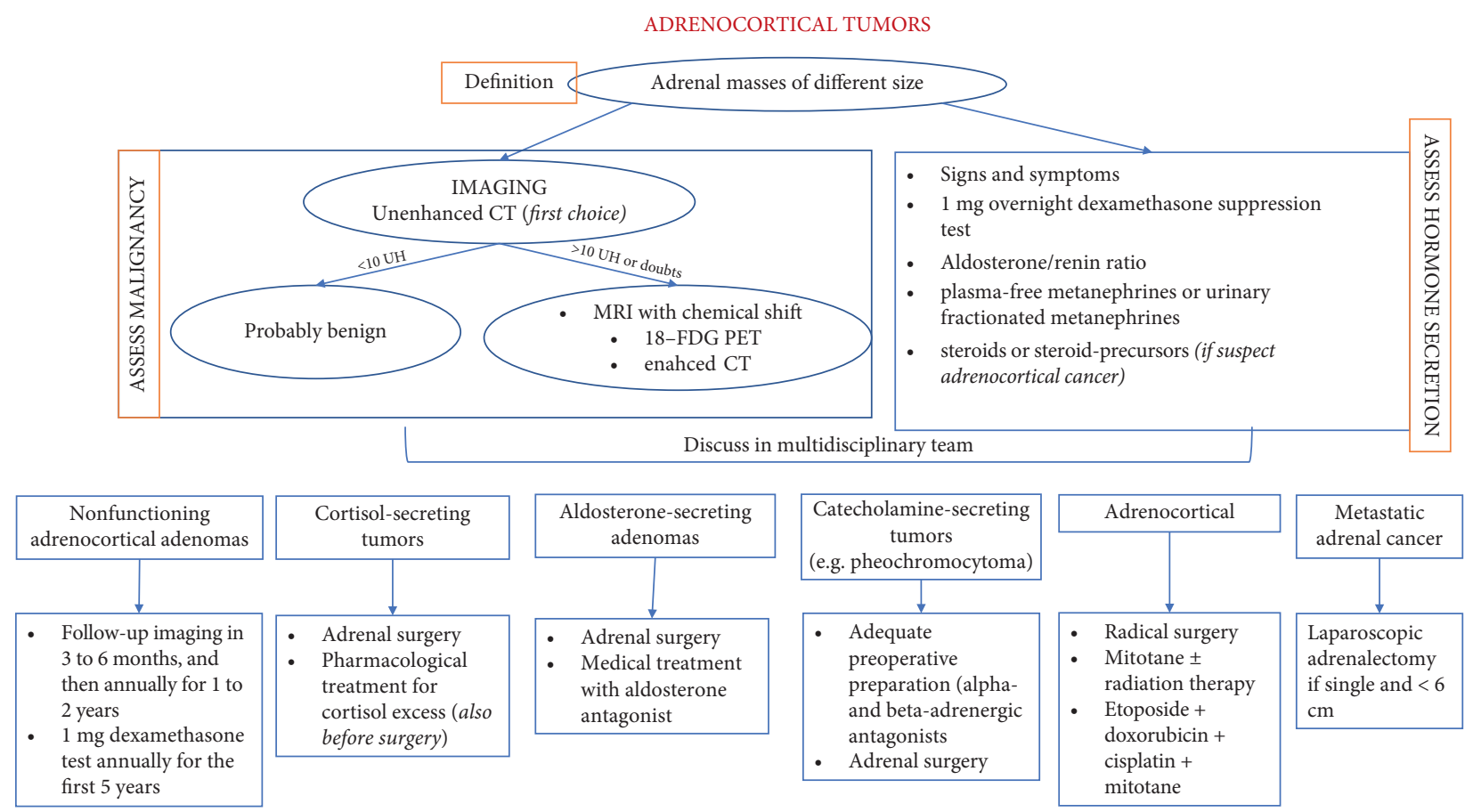

FIGURE 1: Diagnostic and therapeutic flow chart of adrenocortical tumors. 18-FDG PET, positron emission tomography with 18F-2-deoxyd-glucose; CT, computed tomography; MRI, magnetic resonance imaging; HU, Hounsfield units.

order to control hypertension and hypokalemia. Even patients with a single adrenal mass at imaging technique could have bilateral aldosterone secretion [26]. Therefore, adrenal venous sampling (AVS) is the gold standard in distinguishing unilateral from bilateral secretion and most endocrine surgeons recommend AVS prior to adrenalectomy [27].

2.4. Catecholamine-Secreting Tumors. Facing with an adrenal tumor needs a plasma-free metanephrines or urinary fractionated metanephrines dosage, even if it appears to be cortical, to exclude a pheochromocytoma. This screening is safe and cost-effective [7, 28]. For detailed description, we refer to the recent guidelines of different societies [28].

\subsection{Nonfunctioning Adrenocortical Adenomas.} Nonfunctioning adrenocortical adenomas represent the vast majority of adrenocortical tumors and account for about $80 \%$ [7]. There are conspicuous differences between the most recent American and European guidelines in the management of this kind of adrenal tumors. The American ones published in 2009 recommend that silent adrenocortical tumors $<40 \mathrm{~mm}$ with clear benign imaging features should undergo follow-up imaging in 3 to 6 months, and then annually for 1 to 2 years. Indeed, they reported a risk of an increase of $14 \%$ at 2 years and $29 \%$ at 5 years. Due to the risk (47\%) of becoming hormonally active with a great prevalence of "possible autonomous cortisol secretion," they also recommend hormonal evaluation annually for the first 5 years [29]. Differently, the European Society of Endocrinology Clinical Practice Guidelines do not recommend imaging follow-up in silent adrenal tumors $<40 \mathrm{~mm}$ without malignant or suspicious for malignancy radiological features; furthermore, the guidelines also do not recommend repeating the hormonal assessment unless clinical signs of excess develop [7].

2.6. Metastatic Adrenal Cancer. In patients with a prior cancer history, the possible secondarism of an adrenocortical lesion should always be kept in mind [30]. The primary cancers that more frequently metastasize to adrenal glands are lung, breast, colon, and melanoma [31]. Bilateral adrenal metastasis rarely causes adrenal insufficiency [7]. A single adrenal metastasis may often be treated by laparoscopic adrenalectomy if it is $<6 \mathrm{~cm}$, and extended survival or even cure could be achieved [32-35].

\section{Adrenocortical Cancer}

ACC is a rare but extremely aggressive malignancy with poor prognosis [36, 37]. To date, radical (R0) surgery is the best treatment and the only one that can have a curative aim [38]. However, ACC shows a very high rate of recurrence (40-65\% at 2 years) and the emergence of distant metastasis is frequent also in patients with R0 $[39,40]$. Thus, ACC has a survival rate of $50 \%$ after 5 years and adjuvant therapy plays a pivotal role in the management of this malignancy $[41,42]$. Hypersecretion of adrenal steroids is present in about $60 \%$ of cases with a predominance of hypercortisolism and hyperandrogenism in women. Estrogen-secreting ACC is rare, but if hyperestrogenism is present, it is pathognomonic for ACC $[43,44]$. Of note that nonsecretory ACCs actually produce steroids or steroid precursors in at least $95 \%$ of cases when urinary metabolites are investigated with more 
sensitive methods [45]. Unenhanced CT or MRI is often enough to distinguish between benign and malignant adrenal masses, but in doubtful cases, enhanced CT or 18-FDG PET may be useful $[12,46-48]$. The ENSAT tumor stage is a staging system proposed by the European Network for the Study of the Adrenal Tumors (ENSAT) that guarantees a better prognosis than the previous TNM classification [49].

Unfortunately, most of the recommendations in ACC therapy derive from retrospective studies or expert opinions due to the rarity of the disease. The best ACC treatment is essentially based on the feasibility of radical surgery [50]. About $50 \%$ of ACCs that have been completely surgically removed (R0) relapse till a patient's exitus [51-53]. In the most recent guidelines by the European Society of Endocrinology (ESE), mitotane remains the main drug for primary or adjuvant therapy for recurrent or relapsing disease, used alone or combined with other chemotherapeutics [54]. The ESE defines patients at high risk of recurrence after R0 surgery on the basis of ENSAT tumor stage III or IV or Ki67 > 10\% and suggests adjuvant mitotane treatment in this group. Differently in low-intermediate risk of recurrence after R0 surgery, adjuvant mitotane remains an option to be discussed on individual basis [54]. In case of nonradical surgery (Rx o R1), the ESE suggests adjuvant mitotane treatment plus radiation therapy. The subsequent follow-up must be modulated according to the development of relapses. In advanced ACC, chemotherapy associated with mitotane is the standard of cure in combination with debulking surgery, but the outcomes remain little motivating, owing to the scarce response with no impact on overall survival (OS) and the significant toxicity [55]. The real utility of radiotherapy and other locoregional treatment is still debated [56]. The etoposide, doxorubicin, cisplatin plus mitotane (EDP-M) regimen represents the most widely accepted treatment for advanced ACC, being validated by a randomized controlled trial [55]. In case of disease progression under EDP-M regimen, additional therapies (other chemotherapy or minimally invasive procedures) or enrollment in experimental clinical trials should be consider [54].

\section{Cell and Animal Models of Adrenocortical Carcinoma}

The human adrenal cortex is a complex endocrine organ that secretes mineralocorticoids, glucocorticoids, and adrenal androgens that arise from morphologically and biochemically distinct zones of the adrenal gland [57]. Indeed, the most common form of endocrine hypertension results from the excessive secretion of aldosterone from the adrenal. However, understanding the underlining molecular mechanism of aldosterone synthesis and release is hampered by the lack of a suitable human adrenocortical cell line that reflects the molecular retaining ability to produce any of the major adrenal steroid products that faithfully reflect aldosterone-producing adenomas [57-59]. As well, clinical translation of novel therapeutic strategies for patients with ACC often fails [60] especially in children with advanced ACC where conventional chemotherapeutic agents have shown limited utility and efficacy [61]. These disappointing results indicate that the current tumor models only poorly reflect relevant pathophysiology and, thereby, do not predict clinical applicability of novel pharmacological approaches [60]. Overall, the development of novel anticancer agents heavily relied on xenograft models of human cancers. Nonetheless, they have specific limitations and variables, such as tumor origin, subculturing, genetic background, immune-competence of the murine host, hormonal activity, or site of implantation. These have to be individually taken into account for the design of preclinical studies on ACC. Cell-culture-derived xenograft models allow the establishment of metastatic or orthotopic models and the use of transfectants expressing luciferase or green fluorescent protein suitable for an in vivo imaging system [62]. Even if commonly available xenografts such as NCI-H295R, Y1, and SW-13 are productive, they derived from long-term in vitro culture susceptible to alteration of their original biological properties through selection pressure in cell cultures compared to the original patient tumors [63]. To overcome this limitation, patient-derived tumor xenografts engrafted in immunodeficient mice have been established and tested for a variety of cancer types [60]. Tumor graft models (also known as patient-derived xenografts or PDXs) are based on the transfer of primary tumors directly from the patient into an immunodeficient mouse. Because PDX mice are derived from human tumors, they offer a tool for developing anticancer therapies and personalized medicine for patients with cancer [63]. Though, they require surgery, not always available in all animal laboratories. In addition, as the exact number of cells required for inoculation is unknown, tumor inoculation is difficult to perform. However, they reflect tumor heterogeneity and do not require mincing and subculturing [63]. Regrettably, no cell line derived from this xenograft is available for in vitro experiments [60]. In the meantime, the use of a panel of tumor models of NCIH295R, SJ-ACC3, and MUC-1 xenograft models could help the clinical translation of therapeutic regimens in the future (Table 1). In fact, in a long-term treatment regimen, this panel displayed model-dependent differences in therapeutic outcomes with specific chemotherapeutic regimens again reflecting the high heterogeneity of ACC patients [75].

4.1. YI Mouse Cell Line. The initial model of the ACC originated from LAF1 mice by exposure to the irradiation of a test atomic bomb explosion. Cohen et al. succeeded to transplant the generated ACC into mice, and the transplanted tumor caused the malignant phenotype. By necropsy, they showed numerous small lung metastases characterized by atrophy of the zona glomerulosa and confirmed by the coexisting hypernatremia and polyuria, with early drop in levels of eosinophils. However, no significant change in the mouse pituitary bodies of the tumorbearing mice was observed, suggesting the model's inability to secrete adrenocortical hormones such as cortisone and hydrocortisone [76]. To address this shortage, a clone secreting adrenocortical hormones and able to cause the malignant phenotype in the LAF1 mouse strain in vivo was 
TABLE 1: Cell line models of ACT.

\begin{tabular}{|c|c|c|c|}
\hline Cell line & Features & Similarity to human adrenocortical cancer & Reference \\
\hline YI & $\begin{array}{l}\text { Derived from LAF1 mice, isolated after different in } \\
\text { vivo passages and then in cell cultures, could } \\
\text { secrete some adrenocortical hormones }\end{array}$ & $\begin{array}{c}\text { Poor (alteration in growth, morphology, or } \\
\text { adrenocortical hormones) }\end{array}$ & {$[64-66]$} \\
\hline $\begin{array}{l}\text { NCI-H295R (H295, } \\
\text { H295R, H295R-S1, } \\
\text { H295R-S2, and H295R- } \\
\text { S3) }\end{array}$ & $\begin{array}{c}\text { Derived from a carcinoma of the adrenal cortex of } \\
\text { a } 48 \text {-year-old female patient diagnosed with ACC, } \\
\text { can produce and secrete human adrenocortical } \\
\text { hormones }\end{array}$ & $\begin{array}{c}\text { High (most commonly used cell line), mouse } \\
\text { xenograft used }\end{array}$ & {$[65,67-71]$} \\
\hline SJ-ACC3 & $\begin{array}{l}\text { Derived from a tumor of an 11-year-old boy } \\
\text { harboring a germline TP53 G245C mutation }\end{array}$ & $\begin{array}{l}\text { Medium (it resembles genetic childhood } \\
\text { ACC), mouse xenograft used }\end{array}$ & {$[61]$} \\
\hline SW-13 & $\begin{array}{l}\text { Derived from a metastatic depot in the adrenal } \\
\text { cortex of a 55-year-old Caucasian female with a } \\
\text { small cell carcinoma (lung), no hormonal secretion }\end{array}$ & $\begin{array}{c}\text { Poor (roughly considered an ACC cell line; } \\
\text { however, frequently used as a control cell } \\
\text { line), mouse xenograft used }\end{array}$ & {$[72]$} \\
\hline MUC-1 & $\begin{array}{c}\text { Derived from an ACC patient with an adrenal mass } \\
\text { of } 22 \mathrm{~cm} \text { engrafted in mice and then explanted, } \\
\text { genetic and molecular characteristics of MUC-1 } \\
\text { cells have a distinct marker profile, if compared } \\
\text { with NCI-H295R }\end{array}$ & $\begin{array}{l}\text { High (even if mouse-conditioned), mouse } \\
\text { xenograft used }\end{array}$ & {$[60]$} \\
\hline CU-ACC1 & $\begin{array}{c}\text { Derived from a patient with a perinephric } \\
\text { metastasis whose primary tumor secreted } \\
\text { aldosterone }\end{array}$ & $\begin{array}{l}\text { Medium (it resembles aldosterone- } \\
\text { producing adenoma) }\end{array}$ & [73] \\
\hline CU-ACC2 & $\begin{array}{l}\text { Derived from a patient with liver metastasis and } \\
\text { Lynch syndrome }\end{array}$ & Low (roughly considered an ACC cell line) & [73] \\
\hline CU-ACC9 & $\begin{array}{l}\text { Derived from a cortisol-producing ACC involving } \\
\text { adrenal, kidney, and distal pancreas with an } \\
\text { inferior vena cava (IVC) thrombus in a 55-year-old } \\
\text { female }\end{array}$ & $\begin{array}{l}\text { Medium (it resembles cortisol-producing } \\
\text { ACC, suggestive of Lynch syndrome) }\end{array}$ & [74] \\
\hline
\end{tabular}

generated from the later $[64,66]$. This offered a huge opportunity at that time when a suitable human model of ACCs was uncommon. In fact, this model has been used by many investigators [65]. However, the YI line poorly mimics human ACC as it presents uncommon properties in the growth, morphology, or adrenocortical hormones involved in steroidogenesis [65].

4.2. NCI-H295R. NCI-H295R is a pluripotent ACC cell line established by Gazdar et al. from a carcinoma of the adrenal cortex of a 48-years-old female patient diagnosed with ACC $[65,77]$. The cell line is a suitable model of hyperaldosteronism in relation to different culture conditions that retain the ability to produce adrenal androgens [57, 59, 65]. NCI-H295R cells predominantly secrete cortisol, while aldosterone and other steroids are released at much lower concentrations. Indeed, aldosterone output specifically increases in response to different stimuli such as potassium ion, ACTH, and angiotensin II in a dose-dependent manner [59, 65]. Moreover, the cell line has proved value in studying regulation, metabolic pathways, and enzymes involved in steroid formation and secretion [65]. Various sets of cells growing rapidly and with better monolayer attachment have been developed based on the serum supplement used for growth to mitigate the slow growth rates and easy detachment of the original NCI-H295 strains. This includes H295R-S1, H295R-S2, and H295R-S3 [77, 78]. NCI-H295R-derived spheroids release higher aldosterone concentration resulting from higher expression levels of the steroidogenic enzymes steroidogenic acute regulatory protein (StAR), 3 $\beta$-hydroxysteroid dehydrogenase ( $3 \beta$-HSD), cytochrome (CYP) 17, SF-1 (steroidogenic factor 1 ), and the melanocortin 2 (MC2) receptor and the presence of epithelial growth factor (EGF) and fibroblast growth factor (FGF) in the culture medium [59]. As well, the human adrenocortical tumor $\mathrm{H} 295$ cell line is a model to evaluate mechanisms controlling CYP19 and CYP21 steroid production [71]. Xenografts produced all three classes of adrenal steroids, with the preferential production of androgens of the $\Delta 4$ pathway. The NCI-H295R xenograft model induced after subcutaneous injection of $6 \times 10^{6}$ cells into female nude mice displayed high levels of plasma steroid similar to that of the original patient tumor with a take-on rate in the range of $90 \%$ and a medium doubling time of 12 days [70]. The H295R xenograft model is a good model of human ACC, as it mimics dysregulation of the IGF system usually found in these tumors. It also produces IGF-binding protein-2 and steroids that can be used as tumor markers for preclinical evaluation of existing clinical treatment regimens [69, 70, 79-81]. The subcutaneous NCI-H295R xenografts have also been utilized upon genetic modification to study the role of the betacatenin pathway in the context of adrenocortical tumorigenesis [68]. This model may be useful for evaluating therapeutic agents $[65,70]$ as well as for the development of novel therapeutic strategies [68, 69]. Indeed, NCI$\mathrm{H} 295 \mathrm{R}$ is the main cell model used in drug discovery against ACC. For example, abiraterone acetate, a potent inhibitor of 17alpha-hydroxylase/17, 20-lyase, a key 
enzyme of adrenal steroidogenesis that rapidly decreases cortisol, has been used in in vitro and in NCI-H295R xenograft models with interesting results [67]. As well, screening inhibitors of TOP2A overexpressed in ACC, which regulates cellular proliferation and invasion in ACC cells, has successfully been used to identify aclarubicin, a good drug candidate for clinical trials in patients with locally advanced and metastatic ACC [82]. However, the use of the cell model for drug discovery and development suggests a poor reproducibility of therapeutic action between different clones of the most commonly used tumor cell model NCI-H295R [60].

4.3. SJ-ACC3. An SJ-ACC3 cell model was established from a tumor of an 11-year-old boy harboring a germline TP53 G245C mutation. A subcutaneous xenograft with SJ-ACC3 in immunocompromised CB17 scid-/- mice has been generated [61]. The xenograft maintained the histopathologic and molecular features of the original tumor with endocrine functionality, positivity for inhibin- $\alpha$, keratin 8 , synaptophysin, a strong nuclear p53 staining, and a Ki67 index of approximately $60 \%$, with no detectable chromogranin, HMB-45, and S-100. Even though it is tissue based and not cell-line based, SJ-ACC3 represents a quite standardizable tumor model confirmed by successful reimplantation after defreezing. Screening the xenograft for drug responsiveness showed that cisplatin had a potent antitumor effect. However, etoposide, doxorubicin, and a panel of other common cancer drugs had little or no antitumor activity, with the exception of topotecan, which was found to significantly inhibit tumor growth [61]. The authors concluded that topotecan could be a potentially effective agent for treating ACC in childhood [61].

4.4. SW-13. SW-13 human Caucasian adrenal cortex adenocarcinoma was derived from biopsy tissue of a small cell carcinoma originating in the adrenal cortex of a 55-year-old Caucasian female [72]. This SW-13 cell line was established by Leibovitz et al. in [72] from an undifferentiated small cell carcinoma of lung [72]. SW-13 can be roughly considered an ACC cell line, as it derives from a small cell carcinoma metastasized in the adrenal gland [60].

SW-13 xenografts displayed important angiogenic pathways in ACC that can be used to identify antitumor agents with VEGF receptor tyrosine kinase inhibition properties [62]. Notably, everolimus alone significantly reduced tumor growth in SW13 xenografts, in accordance with the very high percentage of apoptosis seen in in vitro experiments. Moreover, sorafenib plus everolimus simultaneous inhibition of several signaling pathways may be a more effective anticancer, suggesting that antiangiogenic drugs may have considerable therapeutic potential for ACC [62]. As well, nanoparticle albumin-bound paclitaxel (nab-paclitaxel) showed better anti-ACC potency in SW-13 tumor-bearing mice than the adrenolytic substance mitotane [83]. Cyclophosphamide administration in SW-13 xenograft mice selectively kills cancer cells without toxicity to cancer stem cells (CSCs) and thereby provides a practical approach for achieving the enrichment of CSCs in ACC [84]. As well, Wolkersdörfer et al. demonstrated the efficacy of suicide gene therapy, a HSV thymidine kinase expressing adenoviral shuttle, is significantly amplified by viral replication and, in combination with ganciclovir, significantly reduces tumor burden and increases survival time in SW-13 xenografts in nude mice injected with $10 \times 10^{6}$ cells [85]. It is noteworthy that SW-13 cells represent a depot to the adrenal of a primitive lung carcinoma and thus have genetic and molecular background that reflects the tissue origin (i.e., no synthesis of adrenal hormones, harbored mutated TP53, and wild-type CTNNB1).

4.5. MUC-1. Hantel et al. established a novel patient-derived tumor model that can improve clinical prediction of therapeutic strategies for ACC patients. The affected patient had an adrenal mass of $22 \mathrm{~cm}$ diagnosed as ACC, which has been used to develop a MUC-1 mouse xenograft. This model showed extraordinary engraftment properties and sustained tumor growth over several passages in the murine host with sustained nuclear SF- 1 and cytoplasmic $3 \beta-H S D$ immunopositivity, high vascularization, and proliferation [60]. In contrast to the majority of the adrenal patient-derived xenograft, MUC-1 xenografts showed the engraftment of large solid tumors, marked tumor growth, and the maintenance of pathological and endocrine features. Moreover, a primary cell line was established from explanted MUC-1 xenograft pieces, called MUC-1 cells. Differently to NCI-H295R, MUC-1 cells were not responsive to the current systemic gold standard EDP-M treatment [60]. Moreover, genetic and molecular characteristics of MUC-1 cells revealed a distinct marker profile, if compared with NCI-H295R and SW-13 cells, with nuclear p53 and cytoplasmic $\beta$-catenin staining. Thereby, MUC- 1 cells were recently authenticated and certified as a novel ACC cell line of human origin [60].

4.6. CU-ACC 1, 2, and 9. CU-ACC1 cell lines derived from a patient with a perinephric metastasis whose primary tumor secreted aldosterone, while CU-ACC2 cell lines derived from a patient with liver metastasis and Lynch syndrome [73]. CU-ACC1 cells carry a mutation in CTNNB1 and secreted cortisol, but not aldosterone, while CU-ACC2 cells show a TP53 mutation and loss of MSH2, consistent with the patient's known germline mutation causing Lynch syndrome. Short tandem repeat profiling confirmed consistent matches between human samples and models. Both cell lines can be transfected and transduced with similar growth rates and have been used to create a PDX. RNA sequencing and immunohistochemistry confirmed the expression of adrenal cortex markers in the PDXs and human tumors. These new preclinical models of ACC significantly advance the field by allowing investigation of underlying molecular mechanisms of ACC and the ability to test patient-specific therapeutic targets. These new cell lines replicate two of the known genetic models of ACC [73]. A third ACC PDX, CU-ACC9, was established from a mild cortisol producing $15 \mathrm{~cm}$ primary ACC tumor 
involving adrenal, kidney, and distal pancreas with an inferior vena cava (IVC) thrombus in a 55 -year-old female patient [74]. CU-ACC9 tumor tissue carries a T53 p.R248W mutation, intermediate microsatellite instability, and loss of MSH2 and MSH6 staining, all suggestive of Lynch syndrome. It expresses the common adrenal markers inhibin- $\alpha$ and SF-1 and high MELK, a kinase identified as a potential therapeutic target in ACC. This model has successfully been used to test the efficacy of OTSSP167 (MELK inhibitor) in the CU-ACC9 PDX model [74].

\section{Phytochemicals Used in Preclinical Studies}

The use of plant natural compounds in cancer is still a matter of debate since human clinical trials testing their usefulness are very scarce and difficult to accomplish, even if some limited results have been reported [86]. Currently, no data are available on the experimentation of phytochemicals in patients affected by ACC or ACT [87]. Nonetheless, different preclinical works have been published, and this section summarizes the available research on ACT and ACC treated with plant natural compounds (Table 2).

5.1. Apigenin. Apigenin (4',5,7-trihydroxyflavone) (Figure 2) is a naturally occurring flavonoid present in a wide range of plants including Asteraceae, Lamiaceae, and Fabaceae families $[105,106]$. Apigenin has been used in traditional medicine for its antioxidant, anti-inflammatory [107], antibacterial, and antiviral activities [108], in addition to its capacity in reducing blood pressure [109]. Furthermore, apigenin was proven to have tumor suppression efficacy via different signaling pathways including NF- $\kappa \mathrm{B}$, PI3K/Akt, JAK/STATs, AMPK, Wnt/ $\beta$-catenin, MAPK/ERK, and JNK and could inhibit cell cycle progression and cell migration and invasion. It could also trigger immune response, autophagy, and cell apoptosis [110]. The protective role of apigenin against multiple types of cancer has been widely reported, for example, in breast [111], cervical [112], colon [113], leukemia [114], lung [115], prostate [116], skin [117], thyroid [118], endometrial [119], neuroblastoma [120], and adrenocortical cancers [94].

Laboratory studies revealed an increased expression of Wnt, frizzle, or lymphoid enhancer factor (LEF)/T cell factor (TCF) in patients with adrenocortical tumors [121]. Apigenin was found to significantly reduce the amount of total, cytoplasmic, and nuclear $\beta$-catenin and the expression of Wnt target genes in a dose-dependent manner, thereby suppressing cell proliferation, migration, and invasion of cancer cells [122]. Lin et al. also showed that the autolysosomal degradation of $\beta$-catenin induced by apigenin occurred via inhibition of the Akt/mTOR signaling pathway at concentrations higher than $10 \mu \mathrm{M}$ [122]. Sanderson et al. found that flavonoids was potent aromatase inhibitors and thus increased intracellular cAMP concentrations [122]. Results also indicated that cells exposed to apigenin demonstrated decreased cortisol production and $3 \beta$-HSD II and P450c21 activity at a concentration of $12.5 \mu \mathrm{M}$ [88]. More recently, apigenin was shown to downregulate the expression levels of 3 $\beta$-HSD, CYP17, and CYP21 mRNA, an effect demonstrated by increasing levels of pregnenolone and $17 \alpha$-hydroxyprogesterone in forskolin-stimulated NCI$\mathrm{H} 295 \mathrm{R}$ cells [89]. In addition, apigenin and quercetin (30 to $100 \mu \mathrm{M}$ ) induced cytotoxicity in H295R cells, probably causing the decline of CYP11B1 expression [90]. Thus, this flavonoid could be potentially useful in patients with excessive steroid hormone production, including ACT.

5.2. Resveratrol. Resveratrol (trans-3,5,4'-trihydroxysilbene) (Figure 2) is a stilbenoid natural polyphenol found in more than 70 plant species such as tea, pomegranate, berries, and cocoa beans, but it is highly concentrated in the skin and seeds of red grapes [123]. Resveratrol was reported to exhibit many therapeutic benefits including antioxidant and anti-inflammatory properties [124], cardiovascular and neurological protective effects $[125,126]$, and immunomodulatory properties [127]. Its anticancer properties have been confirmed by several in vitro and in vivo studies, which showed that resveratrol is able to induce cell cycle arrest, differentiation, and apoptosis and to inhibit cancer cells proliferation [128]. Resveratrol is believed to target the IGF1R/Akt/Wnt signaling pathway together with downregulation of Bcl-2 expression, activation of caspase-3 and 9, and modulation of p53 expression [129]. Resveratrol can also act as a histone deacetylase inhibitor, decreasing proliferation and inducing apoptosis and autophagy in cancer cells [130]. In vitro studies showed that resveratrol could enhance the efficacy of radiotherapy or chemotherapy [131]. Marti et al. found that resveratrol $(5 \mu \mathrm{M})$ reduced protein expression and enzyme activities of CYP17 and CYP21 in H295R cells. Alterations of CYP17 and CYP21 genes are associated to rare forms of congenital adrenal hyperplasia, a disease characterized by excessive or deficient production of sex steroids [91]. They also proved that only SIRT3 mRNA expression was altered by resveratrol associated with the inhibition of $\mathrm{PKB} / \mathrm{Akt}$ signaling pathway, and thus the authors suggested that resveratrol could reduce androgen production in H295R cells via a sirtuin-dependent mechanism [91]. On the same line, Supornsilchai and collaborators in primary rat adrenocortical cell cultures (in vitro and ex vivo) showed that the polyphenol $(50 \mu \mathrm{M})$ inhibited corticosterone production by targeting cytochrome P450 c21hydroxylase [92]. Moreover, resveratrol (and daidzein) at $10 \mu \mathrm{M}$ slightly increased cortisol production without affecting CYP11B1 gene expression or CYP11B1 enzyme activity [90], an enzyme that catalyzes the final conversion of cortisol from 11-deoxycortisol in the biosynthetic pathway. The author suggested that resveratrol (and daidzein) altered cortisol biosynthesis at an earlier step probably acting on CYP17A1, as the time course of substrate-supported cortisol synthesis showed no increase on cortisol production in H295R-treated cells [90]. Similarly, resveratrol and piceatannol (tested for $24 \mathrm{~h}$ at $1,5,10,25,50 \mu \mathrm{M}$ concentrations) induced a secretion decrease of dehydroepiandrosterone, testosterone, and cortisol and an increase of progesterone. Only resveratrol (not piceatannol) was able to inhibit CYP17A1 activity [93]. The authors detected that resveratrol 
TABle 2: Phytochemicals used in preclinical studies.

\begin{tabular}{|c|c|c|c|c|}
\hline Phytochemical & $\begin{array}{l}\text { Experimental } \\
\text { model }\end{array}$ & Doses & Proposed mechanism of action & Reference \\
\hline \multirow{3}{*}{ Apigenin } & H295R cells & $12.5 \mu \mathrm{M}$ & $\begin{array}{l}\text { Decreased cortisol production and } 3 \beta \text {-HSD II } \\
\text { and P450c21 activity }\end{array}$ & {$[88]$} \\
\hline & $\begin{array}{l}\text { NCI-H295R cells } \\
\text { (forskolin-stimulated) }\end{array}$ & $30 \mu \mathrm{M}$ & $\begin{array}{c}\text { Increased levels of pregnenolone and } 17 \alpha- \\
\text { hydroxyprogesterone and downregulated the } \\
\text { expression levels of } 3 \beta \text {-HSD, CYP17, and CYP } 21 \\
\text { mRNA, reduced deoxycorticosterone and } \\
\text { androstenedione levels, suggesting inhibition of } \\
3 \beta \text {-HSD }\end{array}$ & [89] \\
\hline & H295R cells & $30 \mu \mathrm{M}$ & $\begin{array}{c}\text { Decreased CYP11B1 expression, increased } \\
\text { cytotoxicity }\end{array}$ & {$[90]$} \\
\hline \multirow{4}{*}{ Resveratrol } & \multirow[b]{2}{*}{$\begin{array}{l}\text { Primary rat adrenocortical } \\
\text { cell cultures (in vitro and } \\
\text { ex vivo) }\end{array}$} & $5 \mu \mathrm{M}$ & $\begin{array}{c}\text { Reduced protein expression and enzyme } \\
\text { activities of CYP17 and CYP21, inhibited PKB/ } \\
\text { Akt signaling pathway through sirtuin (SIRT3 } \\
\text { mRNA modification) }\end{array}$ & {$[91]$} \\
\hline & & $50 \mu \mathrm{M}$ & $\begin{array}{l}\text { Inhibited corticosterone production by targeting } \\
\text { cytochrome P450 c21-hydroxylase }\end{array}$ & {$[92]$} \\
\hline & H295R cells & $10 \mu \mathrm{M}$ & $\begin{array}{c}\text { Increased cortisol production without affecting } \\
\text { CYP11B1 gene expression or CYP11B1 enzyme } \\
\text { activity }\end{array}$ & {$[90]$} \\
\hline & H295R cells & $1,5,10,25,50 \mu \mathrm{M}$ & $\begin{array}{l}\text { Induced a secretion decrease of } \\
\text { dehydroepiandrosterone, testosterone, and } \\
\text { cortisol, and an increase of progesterone }\end{array}$ & {$[93]$} \\
\hline Quercetin & H295R cells & $10 \mu \mathrm{M}$ & $\begin{array}{c}\text { Induced aromatase activity and increased } \\
\text { intracellular cAMP concentrations and levels of } \\
\text { the cAMP-dependent pII }\end{array}$ & {$[94]$} \\
\hline Epigallocatechin gallate & NCI-H295 cells & $20 \mu \mathrm{M}$ & $\begin{array}{l}\text { Induced growth inhibition in a dose- and time- } \\
\text { dependent manner, decreased mitochondrial } \\
\text { membrane potential, increased intracellular free } \\
\mathrm{Ca}^{(2+)} \text {, decreased the protein levels of Bcl-2, Bcl- } \\
\text { xl, xIAP, cIAP, Hsp70, and Hsp90, increased the } \\
\text { protein expression of Bad, Bax, Fas/CD95, } \\
\text { cytochrome c, Apaf-1, AIF, GADD153, GRP78, } \\
\text { and caspase-3, 7, 8, and } 9\end{array}$ & {$[95]$} \\
\hline \multirow{4}{*}{ Genistein } & H295R cells & $10 \mu \mathrm{M}$ & 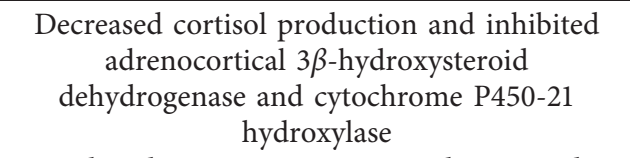 & {$[88]$} \\
\hline & H295R cells & $10 \mu \mathrm{M}$ & $\begin{array}{c}\text { Induced aromatase activity and increased } \\
\text { intracellular cAMP concentrations and levels of } \\
\text { the cAMP-dependent pII }\end{array}$ & {$[94]$} \\
\hline & $\begin{array}{l}\text { Porcine adrenocortical } \\
\text { cells }\end{array}$ & $10 \mu \mathrm{M}$ & $\begin{array}{l}\text { Inhibited secretion of cortisol and corticosterone } \\
\text { via progesterone synthesis inhibition (through } \\
\text { the suppression } 3 \beta \text {-hydroxysteroid } \\
\text { dehydrogenase ( } 3 \beta \text {-HSD) activity) }\end{array}$ & {$[96]$} \\
\hline & H295 cells & $1 \mu \mathrm{M}$ & $\begin{array}{l}\text { Inhibited } 3 \beta \text {-HSD2, CYP21A2, and } 3 \beta \text {-HSD2, } \\
\text { inhibited in vitro the lyase activity, reduced } 17 \text { - } \\
\text { hydroxypregnenolone conversion to } \\
\text { dehydroepiandrosterone (DHEA), decreased } \\
\text { biosynthesis of androgens }\end{array}$ & [97] \\
\hline
\end{tabular}


TABLE 2: Continued.

\begin{tabular}{|c|c|c|c|c|}
\hline Phytochemical & $\begin{array}{l}\text { Experimental } \\
\text { model }\end{array}$ & Doses & Proposed mechanism of action & Reference \\
\hline \multirow[b]{2}{*}{ Daidzein } & $\begin{array}{l}\text { Porcine adrenocortical } \\
\text { cells }\end{array}$ & $10 \mu \mathrm{M}$ & $\begin{array}{c}\text { Inhibited secretion of cortisol and corticosterone } \\
\text { via progesterone synthesis inhibition (through } \\
\text { the suppression } 3 \beta \text {-hydroxysteroid } \\
\text { dehydrogenase ( } 3 \beta \text {-HSD) activity) }\end{array}$ & [96] \\
\hline & H295 cells & $3.1 \mu \mathrm{M}$ & $\begin{array}{l}\text { Inhibited } 3 \beta \text {-HSD2, CYP21A2, and } 3 \beta \text {-HSD2, } \\
\text { inhibited in vitro the lyase activity, reduced } 17- \\
\text { hydroxypregnenolone conversion to } \\
\text { dehydroepiandrosterone (DHEA), decreased } \\
\text { biosynthesis of androgens }\end{array}$ & {$[97]$} \\
\hline \multirow[b]{2}{*}{ Retinoic acid } & H295R cells & $1-20 \mu \mathrm{M}$ & $\begin{array}{c}\text { Reduced DNA synthesis in a dose-dependent } \\
\text { manner }\end{array}$ & {$[98]$} \\
\hline & $\begin{array}{l}\text { NCI-H295R cells and } \\
\text { athymic nude mice } \\
\text { xenografted with H295R } \\
\text { cells }\end{array}$ & $\begin{array}{c}10,25,50,75 \\
100 \mu \mathrm{M}\end{array}$ & $\begin{array}{l}\text { Inhibited cell proliferation and hormone } \\
\text { secretion in cell models, reduced tumor weight in } \\
\text { animal models, implication of cell cycle } \\
\text { regulation by network analysis }\end{array}$ & [99] \\
\hline Osthole & Y1 mouse cells & $100-200 \mu \mathrm{M}$ & $\begin{array}{c}\text { Inhibited cell proliferation, enhanced gene } \\
\text { expression of Star, Cyp11a1, Cyp21a1, Hsd3b2, } \\
\text { Cyp11b1, Cyp17a1, and Hsd17b3, increased } \\
\text { corticosterone secretion in a dose- and time- } \\
\text { dependent manner }\end{array}$ & {$[100,101]$} \\
\hline $\begin{array}{l}\text { Curcumin (curcumin } \\
\text { derivative EF24) }\end{array}$ & SW13 and H295R cells & $\begin{array}{l}\text { IC50 of } 6.5 \text { and } \\
4.9 \mu \mathrm{M}, \\
\text { respectively }\end{array}$ & $\begin{array}{l}\text { Induced subG0/G1 cell cycle phase, reduced cell } \\
\text { migration and colony number, increased reactive } \\
\text { oxygen species, involvement of Wnt/ } \beta \text {-catenin, } \\
\text { NF- } \kappa \mathrm{B}, \mathrm{MAPK} \text {, and PI3k/Akt pathways }\end{array}$ & {$[102]$} \\
\hline $\begin{array}{l}\text { Other compounds: } \\
\text { eriodictyol, hesperetin, } \\
\text { and naringenin }\end{array}$ & $\begin{array}{c}\text { NCI-H295R cells } \\
\text { (forskolin-stimulated) }\end{array}$ & $30 \mu \mathrm{M}$ & $\begin{array}{c}\text { All reduced deoxycorticosterone and } \\
\text { androstenedione levels by the inhibition of } 3 \beta \text { - } \\
\text { HSD }\end{array}$ & [89] \\
\hline \multirow{2}{*}{ Whole plant extracts } & SW13 and H295R cells & $\begin{array}{l}\text { IC50 of } 0.4 \mu \mathrm{g} / \mu \mathrm{L} \\
\text { and } 0.8 \mu \mathrm{g} / \mu \mathrm{L} \\
\text { respectively }\end{array}$ & $\begin{array}{l}\text { Methanolic extract of Origanum vulgare } \\
\text { impacted on colony formation, cell cycle, and } \\
\text { morphological changes, with a prevalence of } \\
\text { necrotic process over apoptosis, MAPK, and } \\
\text { PI3K/Akt pathways involvement }\end{array}$ & [103] \\
\hline & SW13 and H295R cells & $0.5 \mu \mathrm{g} / \mu \mathrm{L}$ in $\mathrm{SW} 13$ & $\begin{array}{c}\text { Methanolic extract of Mentha longifolia } \\
\text { increased subG0/G1 phase, induced cytotoxicity, } \\
\text { in both cell lines. In SW13 cells, the mixture } \\
\text { modulated the MAPK pathway }\end{array}$ & {$[104]$} \\
\hline
\end{tabular}

could inhibit the steroid hormone production by targeting CYP17A1, fundamental in the glucocorticoid biosynthetic pathway. These data suggest that resveratrol can have a role in adrenocortical hormonal production and thus could be potentially useful in the treatment of ACT characterized by dysregulated hormonal synthesis.

5.3. Quercetin. Quercetin (3,3', $4^{\prime}, 5,7$-pentahydroxyflvanone) (Figure 2) is a polyphenolic bioflavonoid generally classified as a flavonol. It is found in a wide variety of fruits and vegetables such as onions, broccoli, berries, and apples as well as tea and red wine [132]. Quercetin appears to have numerous potential beneficial effects mainly long-lasting anti-inflammatory capacities [133]. It was also reported that quercetin possessed antioxidant actions [134], neurological effects [135], and antiviral activities [136] and was also recognized as an anticancer agent [137]. In vitro and in vivo studies showed that quercetin had the ability to inhibit the growth of cancer cells due to its antioxidant properties, which prevent DNA damage [138]. These properties have been demonstrated through the increase of glutathione peroxidase (GSH), superoxide dismutase (SOD), and catalase (CAT) and the inhibition of lipid peroxides [139]. Furthermore, quercetin seems to inhibit angiogenesis by the inhibition of protein kinase C [140]. It also prevents cancer development at a physiological concentration of $5 \mu \mathrm{M}$ by upregulating p53 and increasing the expression of Bax [141]. Its supplementation at doses greater than $30 \mu \mathrm{M}$ can normalize the expression of insulin-like growth factor receptor 1 (IGF-1), Akt, and androgen receptor (AR) [142]. In vitro findings also suggested that quercetin could have a role in reversing drug resistance and increasing the effectiveness of some chemotherapeutics [143]. Sanderson et al. established that quercetin at $10 \mu \mathrm{M}$ induced aromatase activity and increased intracellular cAMP concentrations and levels of the cAMP-dependent pII in H295R human adrenocortical carcinoma cells [94]. Quercetin effectively increased aromatase activity (CYP19), a key enzyme involved in the synthesis of estrogens from androgens, differently from 
<smiles>O=c1cc(-c2ccc(O)cc2)oc2cc(O)cc(O)c12</smiles>

Apigenin<smiles>O=C(O[C@@H]1Cc2c(O)cc(O)cc2O[C@H]1c1cc(O)c(O)c(O)c1)c1cc(O)c(O)c(O)c1</smiles>

(-)-Epigallocatechin gallate<smiles>CC1=C(/C=C/C(C)=C\C=C\C(C)=C\C(=O)O)C(C)(C)CCC1</smiles>

9-cis-Retinoic acid<smiles>Oc1ccc(/C=C/c2cc(O)cc(O)c2)cc1</smiles>

Resveratrol<smiles>O=c1c(-c2ccc(O)cc2)coc2cc(O)cc(O)c12</smiles>

Genistein<smiles>COc1ccc2ccc(=O)oc2c1CC=C(C)C</smiles>

Osthole<smiles>O=c1c(O)c(-c2ccc(O)c(O)c2)oc2cc(O)cc(O)c12</smiles>

Quercetin<smiles>O=c1c(-c2ccc(O)cc2)coc2cc(O)ccc12</smiles>

Daidzein<smiles>COc1cc(/C=C/C(=O)CC(=O)/C=C/c2ccc(O)c(OC)c2)ccc1O</smiles>

Curcumin

FIGURE 2: Schematic representation of main phytochemicals used in adrenocortical tumor.

apigenin and resveratrol and other flavonoids that are recognized as aromatase inhibitors [144].

5.4. Epigallocatechin Gallate. (-)-Epigallocatechin-3-gallate (EGCG) is the major polyphenol in green tea (Camellia sinensis [L.] Kuntze) that has potent antioxidant, anti-inflammatory, and anticarcinogenic properties [145]. It is reported that the galloyl moiety of tea catechins (Figure 2) plays a crucial role in the health benefits of tea catechins including lipid-lowering and antiangiogenic effects $[146,147]$. Rady et al. reviewed the anticancer effects of EGCG and found that concentrations ranging from 10 to $80 \mu \mathrm{M}$ induced apoptosis and controlled cell proliferation and angiogenesis [148]. These effects were mediated by the suppression of tumor-associated proteins and the modulation of different signaling pathways such as the regulation of $\mathrm{NF}-\kappa \mathrm{B}, \mathrm{Wnt} / \beta$-catenin, cyclin D1, p21/WAF1/CIP1, p27/KIP1, and cyclin-dependent kinases [149]. Moreover, EGCG $(5-20 \mu \mathrm{M})$ suppressed Akt and ERK phosphorylation, blocked MAPK (mitogen-activated protein kinase) activity, and enhanced the activation of FOXO transcription factors [150]. $\mathrm{Wu}$ et al. investigated the molecular mechanisms and signal pathways of EGCG on the induction of apoptosis in human adrenal NCI-H295 cancer cells [95]. They showed that EGCG induced growth inhibition in a dose- and time-dependent manner and decreased mitochondrial membrane potential while increasing intracellular free $\mathrm{Ca}^{(2+)}$ [95]. In addition, the polyphenol decremented the protein levels of Bcl-2, Bcl-xl, xIAP, cIAP, Hsp70, and Hsp90 and augmented the protein expression of Bad, Bax, Fas/CD95, cytochrome c, Apaf-1, AIF, GADD153, GRP78, and caspase-3, 7, 8, and 9. It seems that EGCG could trigger apoptosis through different mechanisms involving the death-receptor, mitochondrial, and ER stress pathways. Its action on different targets is probably cell-type or tissue-type related; nevertheless, more work is needed to elucidate this hint.

5.5. Genistein. Genistein (5,7,4'-trihydroxyisoflavone) (Figure 2) is an isoflavone abundantly found in soy and other legumes [151]. It is a selective estrogen receptor modulator (SERM), mainly through ER $\beta$ binding [152]. Besides the specific SERM effects, genistein has also antioxidant properties and was proved to be a specific inhibitor of tyrosine kinases, affecting many signaling pathways such as proteintyrosine kinase (PTK), Akt, NF- $\kappa$ B, matrix metalloproteinases (MMPs) and Bax/Bcl-2 [153, 154]. Several studies have reported that genistein at low concentrations $(5 \mu \mathrm{M})$ modulated various steps of cell cycle, apoptosis, angiogenesis, and metastasis. These anticancer effects are mediated through multiple molecular mechanisms including the enhancement of caspase- 9 and caspase- 3 activities 
and the inhibition of NF- $\kappa \mathrm{B}$ and $\mathrm{Wnt} / \beta$-catenin signaling pathways [155]. It also increased the proapoptotic protein (Bax) and decreased the antiapoptotic protein Bcl-2 [156]. Interestingly, peroxisome proliferator-activated receptors (PPARs) have also emerged as potential therapeutic targets for modulating tumor growth, and genistein at a concentration of $\geq 5 \mu \mathrm{M}$ has been documented to promote apoptosis in tumor cells via targeting PPAR $\gamma$ signaling cascade [157]. Genistein $(10 \mu \mathrm{M})$ has also been shown to decrease the production of cortisol in ACC cells and inhibit adrenocortical $3 \beta$-hydroxysteroid dehydrogenase and cytochrome P450-21 hydroxylase in H295R cells [88]. Genistein (10 $\mu \mathrm{M})$ has been demonstrated to increase aromatase activity in the same cell line and increased aromatase mRNA expression with the concurrent utilization of the CYP19A1 promoters 1.3 and II $[94,158]$.

5.6. Daidzein. Daidzein (7-hydroxy-3-(4-hydroxyphenyl)$4 \mathrm{H}$-chromen-4-one) is a naturally occurring isoflavone found mostly in soybeans and other legumes (Figure 2). The inhibitory effects of daidzein (and genistein) on the secretion of cortisol and corticosterone in porcine adrenocortical cells were related to their ability to suppress the activity of $3 \beta$ hydroxysteroid dehydrogenase ( $3 \beta$-HSD), a key enzyme in the synthesis of glucocorticoids and androstenedione [96]. Mesiano et al. showed significant inhibition of both $3 \beta$ HSD2 and CYP21A2 at $12.5 \mu \mathrm{M}$ and that of $3 \beta-\mathrm{HSD} 2$ at lower concentrations of $1 \mu \mathrm{M}$ genistein and $3.1 \mu \mathrm{M}$ daidzein [97]. In vitro assays with 1 and $10 \mu \mathrm{M}$ daidzein (and genistein) showed that the isoflavone significantly inhibited the lyase activity. It was reported that while $-70 \%$ of 17 hydroxypregnenolone was converted to dehydroepiandrosterone (DHEA) after $24 \mathrm{~h}$ in the absence of isoflavones, only $-33 \%$ was converted to DHEA in the presence of daidzein and $-55 \%$ in the presence of genistein. Lower concentrations $(1 \mu \mathrm{M})$ of both isoflavones also resulted in significant inhibition of the lyase activity and in a decrease of androgen biosynthesis [97].

5.7. Retinoic Acid. Retinoids control critical physiological events including cell growth, differentiation, reproduction, metabolism, hematopoiesis, and apoptosis [159]. Retinoic acid signaling through retinoid $X$ receptor is recognized as a pathogenic pathway in ACC, and ACC has been associated with reduced retinoic acid production [160]. 9-cis retinoic acid (Figure 2) is an active metabolite of vitamin A, which in turn derives from darkgreen leafy vegetables and fruits as provitamin A carotenoids, mainly $\beta$-carotene [161]. In the H295R cell line, 9-cis retinoic acid reduced DNA synthesis in a dosedependent manner ( 1 to $20 \mu \mathrm{M}$ ) [98]. The same authors studied the 9-cis retinoic acid's antitumoral effects in ACC [99], and in an in vitro experiment, 9-cis retinoic acid inhibited cell proliferation and hormone secretion of H295R cells, while in an in vivo experiment, athymic nude mice xenografted with H295R cells corroborated its antitumor activity (reduced tumor weight).
5.8. Osthole. Coumarins from the fruit of Cnidium monnieri (L.) Cusson were tested in a rat model of "Kidney Yang deficiency," a typical condition in Chinese medicine that shares clinical signs of the glucocorticoid withdrawal syndrome [162]. The authors showed that osthole (Figure 2), a derivative of coumarin found in Cnidium monnieri, decreased plasma corticosterone and adrenocorticotropic hormone without affecting the levels of renin, angiotensin II, and aldosterone [163]. Osthole has been also studied in Y1 mouse ACT cells $[100,101]$. At 100 and $200 \mu \mathrm{M}$, osthole inhibited Y1 cell proliferation and the gene expression of Star, Cyp1la1, Cyp21a1, Hsd3b2, Cyp11b1, Cyp17a1, and Hsd17b3 were significantly enhanced [101]. Moreover, at $50 \mu \mathrm{M}$, the corticosterone level was increased. The same authors observed that in Y1 cells, osthole stimulated corticosterone secretion in a dose- and time-dependent manner [100]. The authors suggested that osthole could regulate adrenal cortex function through increasing the expression of steroidogenic enzymes genes and thus the molecule could be potentially used in higher models to verify its efficacy in ACT.

5.9. Curcumin. Curcumin is the main natural polyphenol found in Curcuma longa $\mathrm{L}$. that is widely known for its antioxidant, anti-inflammatory, antimutagenic, antimicrobial, and anticancer properties [164]. A derivative of curcumin is EF24 that shows enhanced solubility if compared with the natural polyphenols. EF24 has been studied in SW13 and H295R cell models in association to mitotane, the reference drug for ACC [102]. The authors showed that EF24 had an antiproliferative effect with IC50 of $6.5 \mu \mathrm{M}$ and $4.9 \mu \mathrm{M}$ for SW13 and H295R cells, respectively, induced subG0/G1 cell cycle phase, reduced cell migration and colony number, and increased reactive oxygen species. Different signaling pathways were altered after EF24 treatment, such as Wnt $/ \beta$-catenin, NF- $\kappa \mathrm{B}, \mathrm{MAPK}$, and PI3k/Akt pathways.

5.10. Other Phytochemicals. Eriodictyol is a tetrahydroxyflavanone isolated from Eriodictyon californicum (Hook. \& Arn.) Torr., while hesperetin is the $4^{\prime}$-methoxy derivative of eriodictyol, naturally occurring as a flavanone glycoside in lemons and sweet oranges [165]. Naringenin is a trihydroxyflavanone widely distributed in several Citrus fruits, bergamot, tomatoes, and other fruits [166]. Hasegawa et al. proved that eriodictyol, hesperetin, and naringenin significantly reduced deoxycorticosterone and androstenedione levels by the inhibition of $3 \beta-H S D$ [89]. It is suggested that such inhibition could be potentially useful in the treatment of adrenocortical hypersecretive diseases, including adrenocortical tumors.

5.11. Whole Plant Extracts. Few works explored the use of crude plant extracts in SW13 and H295R cell models of ACT. One work evaluated a methanolic extract of Origanum vulgare $\mathrm{L}$. collected in the wild and found a cytotoxic activity (IC50) value of $0.4 \mu \mathrm{g} / \mu \mathrm{L}$ for SW13 cells and $0.8 \mu \mathrm{g} / \mu \mathrm{L}$ for H295R cells [103]. Moreover, colony formation, cell cycle, 
and morphological changes were performed, together with a prevalence of necrotic process over apoptosis. MAPK and $\mathrm{PI} 3 \mathrm{~K} / \mathrm{Akt}$ pathways were involved in the antiproliferative effect of oregano. Similarly, a second work explored a collected wild mountain Mentha longifolia (L.) Hudson extract in the same cell lines [104]. The research showed that the extract exerted antiproliferative effect by MTT assay only in SW13 cells at $0.5 \mu \mathrm{g} / \mu \mathrm{L}$, together with an increase in subG0/ G1 phase. No reinforced effect was observed when mint was combined with mitotane; nonetheless, the plant extract modulated the MAPK signaling pathway in SW13 cell lines.

The use of plant crude extract could be a promising strategy to fight cancer, as it uses phytocomplexes rather than a single compound or active molecule [167-169]. This line of research can reserve interesting developments because synergy and/or potentiating effects are at the basis of the phytocomplex; thus, phytochemicals can possess greater effects than the sum of the effects of the individual components [170].

\section{Conclusions and Future Perspectives}

Plant natural products are a precious source of complex and innovative compounds, useful in numerous clinical conditions, including cancer. Phytochemicals are also a source of inspiration for new medicines and supplements, given their high biochemical structure variability. Among this broad category, polyphenols are probably the most studied and represented, for example, curcumin, resveratrol, and quercetin; and they reserve remarkable volumes of literature clinical evidence with anticancer activity, at least in the most common forms of human tumors, i.e., lung, mammary, colorectal, and prostate [171]. These findings are a good omen for the success of antineoplastic therapy also in rare and uncommon cancer, such as ACC. Regrettably, available data in literature and presented in this review cannot permit to conclude that plant natural compounds are a real tool to fight ACC. Data are partial and represented only by preclinical experiments. Rather than to be a limit, this should be considered a stimulus to encourage researchers to spend new resources and energy in the field of plant-derived drugs discovery, with a special emphasis on those biochemical compounds with anticancer activity.

\section{Data Availability}

Data are available on request to the corresponding author.

\section{Conflicts of Interest}

The authors declare no conflicts of interest.

\section{Authors' Contributions}

All the authors contributed to the manuscript. Conceptualization was performed by RP. All the authors collected resources and were responsible for data curation and writing. Literature review analysis was performed by all the authors. Reviewing and editing were carried out by JM and RP. All the authors read and approved the final manuscript.

\section{Acknowledgments}

This work was partially supported by CONICYT PIA/APOYO CCTE AFB170007.

\section{References}

[1] G. M. Cragg and D. J. Newman, "Natural products: a continuing source of novel drug leads," Biochimica et Biophysica Acta (BBA) - General Subjects, vol. 1830, no. 6, pp. 3670-3695, 2013.

[2] E. Patridge, P. Gareiss, M. S. Kinch, and D. Hoyer, "An analysis of FDA-approved drugs: natural products and their derivatives," Drug Discovery Today, vol. 21, no. 2, pp. 204-207, 2016.

[3] H. Yuan, Q. Ma, L. Ye, and G. Piao, "The traditional medicine and modern medicine from natural products," Molecules, vol. 21, no. 5, 2016.

[4] L. T. Ngo, J. I. Okogun, and W. R. Folk, "21st century natural product research and drug development and traditional medicines," Natural Product Reports, vol. 30, no. 4, pp. 584-592, 2013.

[5] T. Isah, "Anticancer alkaloids from trees: development into drugs," Pharmacognosy Reviews, vol. 10, no. 20, pp. 90-99, 2016.

[6] A. Lichota and K. Gwozdzinski, "Anticancer activity of natural compounds from plant and marine environment," International Journal of Molecular Sciences, vol. 19, no. 11, 2018.

[7] M. Fassnacht, W. Arlt, I. Bancos et al., "Management of adrenal incidentalomas: European society of Endocrinology clinical practice guideline in collaboration with the European Network for the study of adrenal tumors," European Journal of Endocrinology, vol. 175, no. 2, pp. G1-G34, 2016.

[8] L. Barzon, N. Sonino, F. Fallo, G. Palu, and M. Boscaro, "Prevalence and natural history of adrenal incidentalomas," European Journal of Endocrinology, vol. 149, no. 4, pp. 273-285, 2003.

[9] F. Mantero, M. Terzolo, G. Arnaldi et al., "A survey on adrenal incidentaloma in Italy1," Journal of Clinical Endocrinology \& Metabolism, vol. 85, no. 2, pp. 637-644, 2000.

[10] G. W. Boland, M. J. Lee, G. S. Gazelle, E. F. Halpern, M. M. McNicholas, and P. R. Mueller, "Characterization of adrenal masses using unenhanced CT: an analysis of the CT literature," American Journal of Roentgenology, vol. 171, no. 1, pp. 201-204, 1998.

[11] M. A. Blake, M. K. Kalra, A. T. Sweeney et al., "Distinguishing benign from malignant adrenal masses: multidetector row CT protocol with 10-minute delay," Radiology, vol. 238, no. 2, pp. 578-585, 2006.

[12] I. Ilias, A. Sahdev, R. H. Reznek, A. B. Grossman, and K. Pacak, "The optimal imaging of adrenal tumours: a comparison of different methods," Endocrine-Related Cancer, vol. 14, no. 3, pp. 587-599, 2007.

[13] A. Sahdev and R. Reznek, "Imaging evaluation of the nonfunctioning indeterminate adrenal mass," Trends in Endocrinology and Metabolism, vol. 15, no. 6, pp. 271-276, 2004.

[14] W. F. Young Jr., "Conventional imaging in adrenocortical carcinoma: update and perspectives," Hormones and Cancer, vol. 2, no. 6, pp. 341-347, 2011.

[15] D. Deandreis, S. Leboulleux, C. Caramella, M. Schlumberger, and E. Baudin, "FDG PET in the management of patients with adrenal masses and adrenocortical carcinoma," Hormones and Cancer, vol. 2, no. 6, pp. 354-362, 2011. 
[16] L. Groussin, G. Bonardel, S. Silvéra et al., "18F-Fluorodeoxyglucose positron emission tomography for the diagnosis of adrenocortical tumors: a prospective study in 77 operated patients," Journal of Clinical Endocrinology \& Metabolism, vol. 94, no. 5, pp. 1713-1722, 2009.

[17] NIH, "NIH state-of-the-science statement on management of the clinically inapparent adrenal mass ("incidentaloma")," NIH consensus and state-of-the-science statements, vol. 19, no. 2, pp. 1-25, 2002.

[18] N. Bharwani, A. G. Rockall, A. Sahdev et al., "Adrenocortical carcinoma: the range of appearances on CT and MRI," American Journal of Roentgenology, vol. 196, no. 6, pp. W706-W714, 2011.

[19] W. F. Young Jr., "Management approaches to adrenal incidentalomas," Endocrinology and Metabolism Clinics of North America, vol. 29, no. 1, pp. 159-185, 2000.

[20] A. Shibli-Rahhal, M. Van Beek, and J. A. Schlechte, "Cushing's syndrome," Clinics in Dermatology, vol. 24, no. 4, pp. 260-265, 2006.

[21] M. Debono, M. Bradburn, M. Bull, B. Harrison, R. J. Ross, and J. Newell-Price, "Cortisol as a marker for increased mortality in patients with incidental adrenocortical adenomas," Journal of Clinical Endocrinology \& Metabolism, vol. 99, no. 12, pp. 4462-4470, 2014.

[22] G. Di Dalmazi, V. Vicennati, S. Garelli et al., "Cardiovascular events and mortality in patients with adrenal incidentalomas that are either non-secreting or associated with intermediate phenotype or subclinical Cushing's syndrome: a 15-year retrospective study," The Lancet Diabetes \& Endocrinology, vol. 2, no. 5, pp. 396-405, 2014.

[23] E. Cyranska-Chyrek, M. Grzymislawska, and M. Ruchala, "Diagnostic pitfalls of adrenal incidentaloma," Endokrynologia Polska, vol. 68, no. 3, pp. 360-377, 2017.

[24] J. M. Hinojosa-Amaya, D. Cuevas-Ramos, and M. Fleseriu, "Medical management of cushing's syndrome: current and emerging treatments," Drugs, vol. 79, no. 9, pp. 935-956, 2019.

[25] J. W. Funder, R. M. Carey, F. Mantero et al., "The management of primary aldosteronism: case detection, diagnosis, and treatment: an endocrine society clinical practice guideline," Journal of Clinical Endocrinology \& Metabolism, vol. 101, no. 5, pp. 1889-1916, 2016.

[26] W. F. Young, A. W. Stanson, G. B. Thompson, C. S. Grant, D. R. Farley, and J. A. Van Heerden, "Role for adrenal venous sampling in primary aldosteronism," Surgery, vol. 136, no. 6, pp. 1227-1235, 2004.

[27] K. Lorenz, P. Langer, B. Niederle et al., "Surgical therapy of adrenal tumors: guidelines from the German association of endocrine surgeons (CAEK)," Langenbeck's Archives of Surgery, vol. 404, no. 4, pp. 385-401, 2019.

[28] J. W. M. Lenders, Q.-Y. Duh, G. Eisenhofer et al., "Pheochromocytoma and paraganglioma: an endocrine society clinical practice guideline," Journal of Clinical Endocrinology \& Metabolism, vol. 99, no. 6, pp. 1915-1942, 2014.

[29] M. A. Zeiger, G. B. Thompson, Q.-Y. Duh et al., "American association of clinical endocrinologists and American association of endocrine surgeons medical guidelines for the management of adrenal incidentalomas," Endocrine Practice, vol. 15, no. 1, pp. 1-20, 2009.

[30] J. T. Lenert, C. C. Barnett Jr., A. P. Kudelka et al., "Evaluation and surgical resection of adrenal masses in patients with a history of extra-adrenal malignancy," Surgery, vol. 130, no. 6, pp. 1060-1067, 2001.
[31] C. T. Bradley and V. E. Strong, "Surgical management of adrenal metastases," Journal of Surgical Oncology, vol. 109, no. 1, pp. 31-35, 2014.

[32] J. A. Glenn, C. M. Kiernan, T. W. F. Yen et al., "Management of suspected adrenal metastases at 2 academic medical centers," The American Journal of Surgery, vol. 211, no. 4, pp. 664-670, 2016.

[33] S. H. Kim, M. F. Brennan, P. Russo, M. E. Burt, and D. G. Coit, "The role of surgery in the treatment of clinically isolated adrenal metastasis," Cancer, vol. 82, no. 2, pp. 389-394, 1998.

[34] V. E. Strong, M. D’Angelica, L. Tang et al., "Laparoscopic adrenalectomy for isolated adrenal metastasis," Annals of Surgical Oncology, vol. 14, no. 12, pp. 3392-3400, 2007.

[35] B. J. Vazquez, M. L. Richards, C. M. Lohse et al., "Adrenalectomy improves outcomes of selected patients with metastatic carcinoma," World Journal of Surgery, vol. 36, no. 6, pp. 1400-1405, 2012.

[36] A. K. Lam, "Adrenocortical carcinoma: updates of clinical and pathological features after renewed world health organisation classification and pathology staging," Biomedicines, vol. 9, no. 2, 2021.

[37] R. Libé, "Adrenocortical carcinoma (ACC): diagnosis, prognosis, and treatment," Frontiers in cell and developmental biology, vol. 3, p. 45, 2015.

[38] A. Stigliano, I. Chiodini, R. Giordano et al., "Management of adrenocortical carcinoma: a consensus statement of the Italian Society of Endocrinology (SIE)," Journal of Endocrinological Investigation, vol. 39, no. 1, pp. 103-121, 2016.

[39] K. Y. Bilimoria, W. T. Shen, D. Elaraj et al., "Adrenocortical carcinoma in the United States," Cancer, vol. 113, no. 11, pp. 3130-3136, 2008.

[40] M. Terzolo, A. Angeli, M. Fassnacht et al., "Adjuvant mitotane treatment for adrenocortical carcinoma," New England Journal of Medicine, vol. 356, no. 23, pp. 2372-2380, 2007.

[41] G. Donatini, R. Caiazzo, C. Do Cao et al., "Long-term survival after adrenalectomy for stage I/II adrenocortical carcinoma (ACC): a retrospective comparative cohort study of laparoscopic versus open approach," Annals of Surgical Oncology, vol. 21, no. 1, pp. 284-291, 2014.

[42] E. D. Vaughan Jr., "Diseases of the adrenal gland," Medical Clinics of North America, vol. 88, no. 2, pp. 443-466, 2004.

[43] T. Else, A. C. Kim, A. Sabolch et al., "Adrenocortical carcinoma," Endocrine Reviews, vol. 35, no. 2, pp. 282-326, 2014.

[44] M. Fassnacht and B. Allolio, "Clinical management of adrenocortical carcinoma," Best Practice \& Research Clinical Endocrinology \& Metabolism, vol. 23, no. 2, pp. 273-289, 2009.

[45] W. Arlt, M. Biehl, A. E. Taylor et al., "Urine steroid metabolomics as a biomarker tool for detecting malignancy in adrenal tumors," Journal of Clinical Endocrinology \& Metabolism, vol. 96, no. 12, pp. 3775-3784, 2011.

[46] G. W. L. Boland, B. A. Dwamena, M. Jagtiani Sangwaiya et al., "Characterization of adrenal masses by using FDG PET: a systematic review and meta-analysis of diagnostic test performance," Radiology, vol. 259, no. 1, pp. 117-126, 2011.

[47] S. Hahner, M. C. Kreissl, M. Fassnacht et al., "Functional characterization of adrenal lesions using [123I]IMTOSPECT/CT," Journal of Clinical Endocrinology \& Metabolism, vol. 98, no. 4, pp. 1508-1518, 2013.

[48] B. K. Park, C. K. Kim, B. Kim, and J. H. Lee, "Comparison of delayed enhanced CT and chemical shift MR for evaluating 
hyperattenuating incidental adrenal Masses1," Radiology, vol. 243, no. 3, pp. 760-765, 2007.

[49] M. Fassnacht, S. Johanssen, M. Quinkler et al., "Limited prognostic value of the 2004 International Union against Cancer staging classification for adrenocortical carcinoma," Cancer, vol. 115, no. 2, pp. 243-250, 2009.

[50] A. Berruti, E. Baudin, H. Gelderblom et al., "Adrenal cancer: ESMO Clinical Practice Guidelines for diagnosis, treatment and follow-up," Annals of Oncology, vol. 23, no. 7, pp. vii131-vii138, 2012.

[51] R. Bellantone, A. Ferrante, M. Boscherini et al., "Role of reoperation in recurrence of adrenal cortical carcinoma: results from 188 cases collected in the Italian National Registry for Adrenal Cortical Carcinoma," Surgery, vol. 122, no. 6, pp. 1212-1218, 1997.

[52] I. G. C. Hermsen, T. M. A. Kerkhofs, G. d. Butter et al., "Surgery in adrenocortical carcinoma: importance of national cooperation and centralized surgery," Surgery, vol. 152, no. 1, pp. 50-56, 2012.

[53] P. Icard, P. Goudet, C. Charpenay et al., "Adrenocortical carcinomas: surgical trends and results of a 253-patient series from the French association of endocrine surgeons study group," World Journal of Surgery, vol. 25, no. 7, pp. 891-897, 2001.

[54] M. Fassnacht, O. M. Dekkers, T. Else et al., "European society of Endocrinology clinical practice guidelines on the management of adrenocortical carcinoma in adults, in collaboration with the European Network for the study of adrenal tumors," European Journal of Endocrinology, vol. 179, no. 4, pp. G1-G46, 2018.

[55] M. Fassnacht, M. Terzolo, B. Allolio et al., "Combination chemotherapy in advanced adrenocortical carcinoma," New England Journal of Medicine, vol. 366, no. 23, pp. 2189-2197, 2012.

[56] B. Polat, M. Fassnacht, L. Pfreundner et al., "Radiotherapy in adrenocortical carcinoma," Cancer, vol. 115, no. 13, pp. 2816-2823, 2009.

[57] W. E. Rainey, I. M. Bird, and J. I. Mason, "The NCI-H295 cell line: a pluripotent model for human adrenocortical studies," Molecular and Cellular Endocrinology, vol. 100, no. 1-2, pp. 45-50, 1994.

[58] I. M. Bird, N. A. Hanley, R. A. Word et al., "Human NCIH295 adrenocortical carcinoma cells: a model for angiotensin-II-responsive aldosterone secretion," Endocrinology, vol. 133, no. 4, pp. 1555-1561, 1993.

[59] U. D. Lichtenauer, I. Shapiro, A. Osswald et al., "Characterization of NCI-H295R cells as an in vitro model of hyperaldosteronism," Hormone and metabolic research =Hormonund Stoffwechselforschung= Hormones et Metabolisme, vol. 45, no. 2, pp. 124-129, 2013.

[60] C. Hantel, I. Shapiro, G. Poli et al., "Targeting heterogeneity of adrenocortical carcinoma: evaluation and extension of preclinical tumor models to improve clinical translation," Oncotarget, vol. 7, no. 48, pp. 79292-79304, 2016.

[61] E. M. Pinto, C. Morton, C. Rodriguez-Galindo et al., "Establishment and characterization of the first pediatric adrenocortical carcinoma xenograft model identifies topotecan as a potential chemotherapeutic agent," Clinical Cancer Research, vol. 19, no. 7, pp. 1740-1747, 2013.

[62] B. Mariniello, A. Rosato, G. Zuccolotto et al., "Combination of sorafenib and everolimus impacts therapeutically on adrenocortical tumor models," Endocrine-Related Cancer, vol. 19, no. 4, pp. 527-539, 2012.
[63] D. Siolas and G. J. Hannon, "Patient-derived tumor xenografts: transforming clinical samples into mouse models," Cancer Research, vol. 73, no. 17, pp. 5315-5319, 2013.

[64] A. I. Cohen and J. Furth, "Corticotropin assay with transplantable adrenocortical tumor slices: application to the assay of adrenotropic pituitary tumors," Cancer Research, vol. 19, no. 1, pp. 72-78, 1959.

[65] A. F. Gazdar, H. K. Oie, C. H. Shackleton et al., "Establishment and characterization of a human adrenocortical carcinoma cell line that expresses multiple pathways of steroid biosynthesis," Cancer Research, vol. 50, no. 17, pp. 5488-5496, 1990.

[66] Y. Yasumura, V. Buonassisi, and G. Sato, "Clonal analysis of differentiated function in animal cell cultures. I. Possible correlated maintenance of differentiated function and the diploid karyotype," Cancer Research, vol. 26, no. 3, pp. 529-535, 1966.

[67] C. Fiorentini, M. Fragni, P. Perego et al., "Antisecretive and antitumor activity of abiraterone acetate in human adrenocortical cancer: a preclinical study," Journal of Clinical Endocrinology \& Metabolism, vol. 101, no. 12, pp. 4594-4602, 2016.

[68] S. Gaujoux, C. Hantel, P. Launay et al., "Silencing mutated beta-catenin inhibits cell proliferation and stimulates apoptosis in the adrenocortical cancer cell line H295R," PloS One, vol. 8, no. 2, Article ID e55743, 2013.

[69] C. Hantel, F. Lewrick, M. Reincke, R. Süss, and F. Beuschlein, "Liposomal doxorubicin-based treatment in a preclinical model of adrenocortical carcinoma," Journal of Endocrinology, vol. 213, no. 2, pp. 155-161, 2012.

[70] A. Logié, P. Boudou, L. Boccon-Gibod et al., "Establishment and characterization of a human adrenocortical carcinoma xenograft model," Endocrinology, vol. 141, no. 9, pp. 3165-3171, 2000.

[71] W. E. Rainey, I. M. Bird, C. Sawetawan et al., "Regulation of human adrenal carcinoma cell (NCI-H295) production of C19 steroids," Journal of Clinical Endocrinology \& Metabolism, vol. 77, no. 3, pp. 731-737, 1993.

[72] A. Leibovitz, W. M. McCombs 3rd, D. Johnston, C. E. McCoy, and J. C. Stinson, "New human cancer cell culture lines. I. SW-13, small-cell carcinoma of the adrenal cortex," Journal of the National Cancer Institute, vol. 51, no. 2, pp. 691-697, 1973.

[73] K. Kiseljak-Vassiliades, Y. Zhang, S. M. Bagby et al., "Development of new preclinical models to advance adrenocortical carcinoma research," Endocrine-Related Cancer, vol. 25, no. 4, pp. 437-451, 2018.

[74] A. Kar, Y. Zhang, B. Yacob et al., "SUN-337 anti-tumorigenic effects of the maternal leucine zipper kinase (MELK) inhibitor, OTSSP167, in pre-clinical in vivo models of adrenocortical carcinomas (ACC)," Journal of the Endocrine Society, vol. 3, no. 1, 2019.

[75] F. Beuschlein, J. Jakoby, S. Mentz et al., "IGF1-R inhibition and liposomal doxorubicin: progress in preclinical evaluation for the treatment of adrenocortical carcinoma," Molecular and Cellular Endocrinology, vol. 428, pp. 82-88, 2016.

[76] A. I. Cohen, J. Furth, and R. F. Buffett, "Histologic and physiologic characteristics of hormone-secreting transplantable adrenal tumors in mice and rats," American Journal of Pathology, vol. 33, no. 4, pp. 631-651, 1957.

[77] T. Wang and W. E. Rainey, "Human adrenocortical carcinoma cell lines," Molecular and Cellular Endocrinology, vol. 351, no. 1, pp. 58-65, 2012. 
[78] W. E. Rainey, K. Saner, and B. P. Schimmer, "Adrenocortical cell lines," Molecular and Cellular Endocrinology, vol. 228, no. 1-2, pp. 23-38, 2004.

[79] F. M. Barlaskar, A. C. Spalding, J. H. Heaton et al., "Preclinical targeting of the type I insulin-like growth factor receptor in adrenocortical carcinoma," Journal of Clinical Endocrinology \& Metabolism, vol. 94, no. 1, pp. 204-212, 2009.

[80] M. Doghman and E. Lalli, "Lack of long-lasting effects of mitotane adjuvant therapy in a mouse xenograft model of adrenocortical carcinoma," Molecular and Cellular Endocrinology, vol. 381, no. 1-2, pp. 66-69, 2013.

[81] C. Hantel, S. Jung, T. Mussack, M. Reincke, and F. Beuschlein, "Liposomal polychemotherapy improves adrenocortical carcinoma treatment in a preclinical rodent model," Endocrine-Related Cancer, vol. 21, no. 3, pp. 383-394, 2014.

[82] M. Jain, L. Zhang, M. He, Y.-Q. Zhang, M. Shen, and E. Kebebew, "TOP2A is overexpressed and is a therapeutic target for adrenocortical carcinoma," Endocrine-Related Cancer, vol. 20, no. 3, pp. 361-370, 2013.

[83] M. J. Demeure, E. Stephan, S. Sinari et al., "Preclinical investigation of nanoparticle albumin-bound paclitaxel as a potential treatment for adrenocortical cancer," Annals of Surgery, vol. 255, no. 1, pp. 140-146, 2012.

[84] W. Zeng, X. Chen, Y. Ma et al., "A novel approach for enriching cancer stem cells from the human SW-13 adrenocortical carcinoma cell line," Anticancer Research, vol. 34, no. 1, pp. 117-123, 2014.

[85] G. W. Wolkersdörfer, S. R. Bornstein, J. N. Higginbotham et al., "A novel approach using transcomplementing adenoviral vectors for gene therapy of adrenocortical cancer," Hormone and Metabolic Research, vol. 34, no. 6, pp. 279-287, 2002.

[86] A. Hosseini and A. Ghorbani, "Therapeutic benets of phytochemicals," Active Phytochemicals from Chinese Herbal Medicines, vol. 5, no. 2, pp. 84-105, 2015.

[87] ClinicalTrials.gov, Clinical Trials, 2020.

[88] S. Ohno, S. Shinoda, S. Toyoshima, H. Nakazawa, T. Makino, and S. Nakajin, "Effects of flavonoid phytochemicals on cortisol production and on activities of steroidogenic enzymes in human adrenocortical H295R cells," The Journal of Steroid Biochemistry and Molecular Biology, vol. 80, no. 3, pp. 355-363, 2002.

[89] E. Hasegawa, S. Nakagawa, M. Sato, E. Tachikawa, and S. Yamato, "Effect of polyphenols on production of steroid hormones from human adrenocortical NCI-H295R cells," Biological and Pharmaceutical Bulletin, vol. 36, no. 2, pp. 228-237, 2013.

[90] L.-C. Cheng and L.-A. Li, "Flavonoids exhibit diverse effects on CYP11B1 expression and cortisol synthesis," Toxicology and Applied Pharmacology, vol. 258, no. 3, pp. 343-350, 2012.

[91] N. Marti, N. Bouchoucha, K.-S. Sauter, and C. E. Flück, "Resveratrol inhibits androgen production of human adrenocortical H295R cells by lowering CYP17 and CYP21 expression and activities," PloS One, vol. 12, no. 3, Article ID e0174224, 2017.

[92] V. Supornsilchai, K. Svechnikov, D. Seidlova-Wuttke, W. Wuttke, and O. Söder, "Phytoestrogen resveratrol suppresses steroidogenesis by rat adrenocortical cells by inhibiting cytochrome P450 c21-hydroxylase," Hormone Research in Paediatrics, vol. 64, no. 6, pp. 280-286, 2005.

[93] A. Oskarsson, C. Spatafora, C. Tringali, and A. O. Andersson, "Inhibition of CYP17A1 activity by resveratrol, piceatannol, and synthetic resveratrol analogs," The Prostate, vol. 74, no. 8, pp. 839-851, 2014.

[94] J. T. Sanderson, J. Hordijk, M. S. Denison, M. F. Springsteel, M. H. Nantz, and M. van den Berg, "Induction and inhibition of aromatase (CYP19) activity by natural and synthetic flavonoid compounds in H295R human adrenocortical carcinoma cells," Toxicological Sciences, vol. 82, no. 1, pp. 70-79, 2004.

[95] P. P. Wu, S. C. Kuo, W. W. Huang et al., “(-)-Epigallocatechin gallate induced apoptosis in human adrenal cancer NCI-H295 cells through caspase-dependent and caspase-independent pathway," Anticancer Research, vol. 29, no. 4, pp. 1435-1442, 2009.

[96] B. Kaminska, R. Ciereszko, M. Kiezun, and L. Dusza, "In vitro effects of genistein and daidzein on the activity of adrenocortical steroidogenic enzymes in mature female pigs," Journal of Physiology and Pharmacology: An Official Journal of the Polish Physiological Society, vol. 64, no. 1, pp. 103-108, 2013.

[97] S. Mesiano, S. L. Katz, J. Y. Lee, and R. B. Jaffe, "Phytoestrogens alter adrenocortical function: genistein and daidzein suppress glucocorticoid and stimulate androgen production by cultured adrenal cortical cells," Journal of Clinical Endocrinology \& Metabolism, vol. 84, no. 7, pp. 2443-2448, 1999.

[98] P. Ferruzzi, E. Ceni, M. Tarocchi et al., "Thiazolidinediones inhibit growth and invasiveness of the human adrenocortical cancer cell line H295R," Journal of Clinical Endocrinology \& Metabolism, vol. 90, no. 3, pp. 1332-1339, 2005.

[99] D. R. Szabó, K. Baghy, P. M. Szabó et al., “Antitumoral effects of 9-cis retinoic acid in adrenocortical cancer," Cellular and Molecular Life Sciences, vol. 71, no. 5, pp. 917-932, 2014.

[100] Z. Pan, Z. Fang, W. Lu, X. Liu, and Y. Zhang, "Osthole, a coumadin analog from cnidium monnieri (L.) cusson, stimulates corticosterone secretion by increasing steroidogenic enzyme expression in mouse $\mathrm{Y} 1$ adrenocortical tumor cells," Journal of Ethnopharmacology, vol. 175, pp. 456-462, 2015.

[101] Z. Q. Pan, L. L. Liang, Z. Q. Fang, X. M. Liu, W. L. Lu, and Y. Y. Zhang, "Effect of osthole on adrenocortical function in Y1 mouse adrenocortical tumor cells," Zhongguo Zhong xi yi jie he za zhi Zhongguo Zhongxiyi jiehe zazhi = Chinese journal of integrated traditional and Western medicine, vol. 36, no. 5, pp. 574-579, 2016.

[102] L. Bertazza, S. Barollo, M. E. Mari et al., "Biological effects of EF24, a curcumin derivative, alone or combined with mitotane in adrenocortical tumor cell lines," Molecules, vol. 24, no. 12, 2019.

[103] B. Rubin, J. Manso, H. Monticelli et al., "Crude extract of Origanum vulgare L. induced cell death and suppressed MAPK and PI3/Akt signaling pathways in SW13 and H295R cell lines," Natural Product Research, vol. 33, no. 11, pp. 1646-1649, 2019.

[104] F. Patti, A. Palmioli, S. Vitalini et al., "Anticancer effects of wild mountain Mentha longifolia extract in adrenocortical tumor cell models," Frontiers in Pharmacology, vol. 10, p. 1647, 2019.

[105] L. Ornano, A. Venditti, Y. Donno, C. Sanna, M. Ballero, and A. Bianco, "Phytochemical analysis of non-volatile fraction of artemisia caerulescenssubsp.densiflora (Viv.) (Asteraceae), an endemic species of la maddalena archipelago (sardinia-Italy)," Natural Product Research, vol. 30, no. 8, pp. 920-925, 2016. 
[106] A. Venditti, C. Frezza, S. Foddai, M. Serafini, and A. Bianco, "A rare bis-rhamnopyranosyl-aromadendrin derivative and other flavonoids from the flowers of Genista cilentina Vals. an endemic species of Southern Italy," Arabian Journal of Chemistry, vol. 12, no. 8, pp. 3921-3926, 2019.

[107] Z. E. Pápay, A. Kósa, B. Böddi et al., "Study on the pulmonary delivery system of apigenin-loaded albumin nanocarriers with antioxidant activity," Journal of Aerosol Medicine and Pulmonary Drug Delivery, vol. 30, no. 4, pp. 274-288, 2017.

[108] B. Özçelik, M. Kartal, and I. Orhan, "Cytotoxicity, antiviral and antimicrobial activities of alkaloids, flavonoids, and phenolic acids," Pharmaceutical Biology, vol. 49, no. 4, pp. 396-402, 2011.

[109] Z.-Y. Zhu, T. Gao, Y. Huang, J. Xue, and M.-L. Xie, “Apigenin ameliorates hypertension-induced cardiac hypertrophy and down-regulates cardiac hypoxia inducible factor- $1 \alpha$ in rats," Food \& Function, vol. 7, no. 4, pp. 1992-1998, 2016.

[110] X. Yan, M. Qi, P. Li, Y. Zhan, and H. Shao, "Apigenin in cancer therapy: anti-cancer effects and mechanisms of action," Cell \& Bioscience, vol. 7, no. 1, p. 50, 2017.

[111] C. Bosetti, L. Spertini, M. Parpinel, P. Gnagnarella, P. Lagiou, and E. Negri, "Flavonoids and breast cancer risk in Italy," Cancer Epidemiology Biomarkers \& Prevention, vol. 14, no. 4, pp. 805-808, 2005.

[112] P.-W. Zheng, L.-C. Chiang, and C.-C. Lin, "Apigenin induced apoptosis through p53-dependent pathway in human cervical carcinoma cells," Life Sciences, vol. 76, no. 12, pp. 1367-1379, 2005.

[113] W. Wang, L. Heideman, C. S. Chung, J. C. Pelling, K. J. Koehler, and D. F. Birt, "Cell-cycle arrest at G2/M and growth inhibition by apigenin in human colon carcinoma cell lines," Molecular Carcinogenesis, vol. 28, no. 2, pp. 102-110, 2000.

[114] M. A. Vargo, O. H. Voss, F. Poustka, A. J. Cardounel, E. Grotewold, and A. I. Doseff, "Apigenin-induced-apoptosis is mediated by the activation of PKC $\delta$ and caspases in leukemia cells," Biochemical Pharmacology, vol. 72, no. 6, pp. 681-692, 2006.

[115] M. Piantelli, C. Rossi, M. Iezzi et al., "Flavonoids inhibit melanoma lung metastasis by impairing tumor cells endothelium interactions," Journal of Cellular Physiology, vol. 207, no. 1, pp. 23-29, 2006.

[116] S. Gupta, F. Afaq, and H. Mukhtar, "Selective growth-inhibitory, cell-cycle deregulatory and apoptotic response of apigenin in normal versus human prostate carcinoma cells," Biochemical and Biophysical Research Communications, vol. 287, no. 4, pp. 914-920, 2001.

[117] H. Chandra Pal, K. Marchiony Hunt, A. Diamond, C. A. Elmets, and F. Afaq, "Phytochemicals for the management of melanoma," Mini Reviews in Medicinal Chemistry, vol. 16, no. 12, pp. 953-979, 2016.

[118] J. Schroder-Van Der Elst, D. Van Der Heide, J. Romijn, and J. Smit, "Differential effects of natural flavonoids on growth and iodide content in a human $\mathrm{Na}^{*} / \mathrm{I}$ - symporter-transfected follicular thyroid carcinoma cell line," European Journal of Endocrinology, vol. 150, no. 4, pp. 557-564, 2004.

[119] S. A. O'Toole, B. L. Sheppard, O. Sheils, J. J. O'Leary, B. Spengler, and V. Christoffel, "Analysis of DNA in endometrial cancer cells treated with phyto-estrogenic compounds using comparative genomic hybridisation microarrays," Planta Medica, vol. 71, no. 5, pp. 435-439, 2005.

[120] R. Torkin, J. F. Lavoie, D. R. Kaplan, and H. Yeger, "Induction of caspase-dependent, p53-mediated apoptosis by apigenin in human neuroblastoma," Molecular Cancer Therapeutics, vol. 4, no. 1, pp. 1-11, 2005.

[121] A. El Wakil and E. Lalli, "The Wnt/beta-catenin pathway in adrenocortical development and cancer," Molecular and Cellular Endocrinology, vol. 332, no. 1-2, pp. 32-37, 2011.

[122] C.-M. Lin, H.-H. Chen, C.-A. Lin, H.-C. Wu, J. J.-C. Sheu, and H.-J. Chen, "Apigenin-induced lysosomal degradation of $\beta$-catenin in Wnt $/ \beta$-catenin signaling," Scientific Reports, vol. 7, no. 1, p. 372, 2017.

[123] P. Detampel, M. Beck, S. Krähenbühl, and J. Huwyler, "Drug interaction potential of resveratrol," Drug Metabolism Reviews, vol. 44, no. 3, pp. 253-265, 2012.

[124] J. Gambini, M. Ingles, G. Olaso et al., "Properties of resveratrol: in vitro and in vivo studies about metabolism, bioavailability, and biological effects in animal models and humans," Oxidative medicine and cellular longevity, vol. 2015, Article ID 837042, 13 pages, 2015.

[125] S. Andrade, M. J. Ramalho, M. D. C. Pereira, and J. A. Loureiro, "Resveratrol brain delivery for neurological disorders prevention and treatment," Frontiers in Pharmacology, vol. 9, p. 1261, 2018.

[126] D. Bonnefont-Rousselot, "Resveratrol and cardiovascular diseases," Nutrients, vol. 8, no. 5, 2016.

[127] K. C. Doh, B.-M. Kim, K. W. Kim, B. H. Chung, and C. W. Yang, "Effects of resveratrol on Th17 cell-related immune responses under tacrolimus-based immunosuppression," BMC Complementary and Alternative Medicine, vol. 19, no. 1, p. 54, 2019.

[128] B. C. Akinwumi, K. M. Bordun, and H. D. Anderson, "Biological activities of stilbenoids," International Journal of Molecular Sciences, vol. 19, no. 3, 2018.

[129] L. Li, R. L. Qiu, Y. Lin et al., "Resveratrol suppresses human cervical carcinoma cell proliferation and elevates apoptosis via the mitochondrial and $\mathrm{p} 53$ signaling pathways," Oncology letters, vol. 15, no. 6, pp. 9845-9851, 2018.

[130] W. Zam and A. Khadour, "Impact of phytochemicals and dietary patterns on epigenome and cancer," Nutrition and Cancer, vol. 69, no. 2, pp. 184-200, 2017.

[131] J. M. Pezzuto, "Resveratrol as an inhibitor of carcinogenesis," Pharmaceutical Biology, vol. 46, no. 7-8, pp. 443-573, 2008.

[132] S. Andres, S. Pevny, R. Ziegenhagen et al., "Safety aspects of the use of quercetin as a dietary supplement," Molecular Nutrition \& Food Research, vol. 62, no. 1, 2018.

[133] Y. Li, J. Yao, C. Han et al., "Quercetin, inflammation and immunity," Nutrients, vol. 8, no. 3, p. 167, 2016.

[134] D. Xu, M. J. Hu, Y. Q. Wang, and Y. L. Cui, "Antioxidant activities of quercetin and its complexes for medicinal application," Molecules, vol. 24, no. 6, 2019.

[135] E. Amanzadeh, A. Esmaeili, S. Rahgozar, and M. Nourbakhshnia, "Application of quercetin in neurological disorders: from nutrition to nanomedicine," Reviews in the Neurosciences, vol. 30, no. 5, pp. 555-572, 2019.

[136] K. H. Chiow, M. C. Phoon, T. Putti, B. K. H. Tan, and V. T. Chow, "Evaluation of antiviral activities of Houttuynia cordata Thunb. extract, quercetin, quercetrin and cinanserin on murine coronavirus and dengue virus infection," Asian Pacific journal of tropical medicine, vol. 9, no. 1, pp. 1-7, 2016.

[137] A. Rauf, M. Imran, I. A. Khan et al., "Anticancer potential of quercetin: a comprehensive review," Phytotherapy Research, vol. 32, no. 11, pp. 2109-2130, 2018.

[138] L. M. Fadda, H. Hagar, A. M. Mohamed, and H. M. Ali, "Quercetin and idebenone ameliorate oxidative stress, inflammation, DNA damage, and apoptosis induced by titanium dioxide nanoparticles in rat liver," Dose-response: $A$ 
Publication of International Hormesis Society, vol. 16, no. 4, Article ID 1559325818812188, 2018.

[139] X. Wang, G. Fan, F. Wei, Y. Bu, and W. Huang, "Hyperoside protects rat ovarian granulosa cells against hydrogen peroxide-induced injury by sonic hedgehog signaling pathway," Chemico-Biological Interactions, vol. 310, Article ID 108759, 2019.

[140] A. K. Maurya and M. Vinayak, "Improved synergistic anticancer efficacy of quercetin in combination with PI-103, rottlerin, and G0 6983 against MCF-7 and RAW 264.7 cells," In Vitro Cellular \& Developmental Biology-Animal, vol. 55, no. 1, pp. 36-44, 2019.

[141] A. K. Maurya and M. Vinayak, "Anticarcinogenic action of quercetin by downregulation of phosphatidylinositol 3-kinase (PI3K) and protein kinase $\mathrm{C}(\mathrm{PKC})$ via induction of $\mathrm{p} 53$ in hepatocellular carcinoma (HepG2) cell line," Molecular Biology Reports, vol. 42, no. 9, pp. 1419-1429, 2015.

[142] G. Sharmila, F. A. Bhat, R. Arunkumar et al., "Chemopreventive effect of quercetin, a natural dietary flavonoid on prostate cancer in in vivo model," Clinical Nutrition, vol. 33, no. 4, pp. 718-726, 2014.

[143] G. Du, H. Lin, Y. Yang et al., "Dietary quercetin combining intratumoral doxorubicin injection synergistically induces rejection of established breast cancer in mice," International Immunopharmacology, vol. 10, no. 7, pp. 819-826, 2010.

[144] M. Balunas, B. Su, R. Brueggemeier, and A. Kinghorn, "Natural products as aromatase inhibitors," Anti-Cancer Agents in Medicinal Chemistry, vol. 8, no. 6, pp. 646-682, 2008.

[145] J. D. Lambert and R. J. Elias, "The antioxidant and prooxidant activities of green tea polyphenols: a role in cancer prevention," Archives of Biochemistry and Biophysics, vol. 501, no. 1, pp. 65-72, 2010.

[146] I. Ikeda, "Multifunctional effects of green tea catechins on prevention of the metabolic syndrome," Asia Pacific Journal of Clinical Nutrition, vol. 17, no. 1, pp. 273-274, 2008.

[147] T. Kondo, T. Ohta, K. Igura, Y. Hara, and K. Kaji, “Tea catechins inhibit angiogenesis in vitro, measured by human endothelial cell growth, migration and tube formation, through inhibition of VEGF receptor binding," Cancer Letters, vol. 180, no. 2, pp. 139-144, 2002.

[148] L. Chen and H.-Y. Zhang, "Cancer preventive mechanismsof the green tea polyphenol (-)-Epigallocatechin-3-gallate," Molecules, vol. 12, no. 5, pp. 946-957, 2007.

[149] S. Shankar, G. Suthakar, and R. K. Srivastava, "Epigallocatechin-3-gallate inhibits cell cycle and induces apoptosis in pancreatic cancer," Frontiers in Bioscience, vol. 12, no. 12, pp. 5039-5051, 2007.

[150] R. L. H. Bigelow and J. A. Cardelli, “The green tea catechins, (-)-Epigallocatechin-3-gallate (EGCG) and (-)-Epicatechin3-gallate (ECG), inhibit HGF/Met signaling in immortalized and tumorigenic breast epithelial cells," Oncogene, vol. 25, no. 13, pp. 1922-1930, 2006.

[151] N. Jaiswal, J. Akhtar, S. P. Singh, and F. Ahsan, "An overview on genistein and its various formulations," Drug Research, vol. 69, no. 6, pp. 305-313, 2019.

[152] G. G. J. M. Kuiper, J. G. Lemmen, B. Carlsson et al., "Interaction of estrogenic chemicals and phytoestrogens with estrogen receptor $\beta$," Endocrinology, vol. 139, no. 10, pp. 4252-4263, 1998.

[153] T. Akiyama, J. Ishida, S. Nakagawa et al., "Genistein, a specific inhibitor of tyrosine-specific protein kinases," Journal of Biological Chemistry, vol. 262, no. 12, pp. 55925595, 1987.
[154] S. Banerjee, Y. Li, Z. Wang, and F. H. Sarkar, "Multi-targeted therapy of cancer by genistein," Cancer Letters, vol. 269, no. 2, pp. 226-242, 2008.

[155] S. Dhandayuthapani, P. Marimuthu, V. Hörmann, J. KumiDiaka, and A. Rathinavelu, "Induction of apoptosis in HeLa cells via caspase activation by resveratrol and genistein," Journal of Medicinal Food, vol. 16, no. 2, pp. 139-146, 2013.

[156] Y. Luo, S.-X. Wang, Z.-Q. Zhou et al., "Apoptotic effect of genistein on human colon cancer cells via inhibiting the nuclear factor-kappa B (NF- $\kappa \mathrm{B})$ pathway," Tumor Biology, vol. 35, no. 11, pp. 11483-11488, 2014.

[157] H. S. Tuli, M. J. Tuorkey, F. Thakral et al., "Molecular mechanisms of action of genistein in cancer: recent advances," Frontiers in Pharmacology, vol. 10, p. 1336, 2019.

[158] L. Ye, M. Y. Chan, and L. K. Leung, "The soy isoflavone genistein induces estrogen synthesis in an extragonadal pathway," Molecular and Cellular Endocrinology, vol. 302, no. 1, pp. 73-80, 2009.

[159] M. M. Gottardis, W. W. Lamph, D. R. Shalinsky, A. Wellstein, and R. A. Heyman, "The efficacy of 9-cis retinoic acid in experimental models of cancer," Breast Cancer Research and Treatment, vol. 38, no. 1, pp. 85-96, 1996.

[160] P. M. Szabó, V. Tamási, V. Molnár et al., "Meta-analysis of adrenocortical tumour genomics data: novel pathogenic pathways revealed," Oncogene, vol. 29, no. 21, pp. 3163-3172, 2010.

[161] M. A. Kane, "Analysis, occurrence, and function of 9-cisretinoic acid," Biochimica et Biophysica Acta (BBA) - Molecular and Cell Biology of Lipids, vol. 1821, no. 1, pp. 10-20, 2012.

[162] L. Zhao, H. Wu, M. Qiu et al., "Metabolic signatures of kidney yang deficiency syndrome and protective effects of two herbal extracts in rats using GC/TOF MS," EvidenceBased Complementary and Alternative Medicine: eCAM, vol. 2013, Article ID 540957, 10 pages, 2013.

[163] L. P. Qin, J. Q. Zhang, and H. P. Shi, "[Effects of coumarins from cnidium monnieri on the function of pituitary-adrenocortical axis in kidney yang deficiency rats]," Zhongguo Zhong xi yi jie he za zhi Zhongguo Zhongxiyi jiehe zaz$h i=$ Chinese journal of integrated traditional and Western medicine, vol. 17, no. 4, pp. 227-229, 1997.

[164] S. J. Hewlings and D. S. Kalman, "Curcumin: a review of its effects on human health," Foods, vol. 6, no. 10, 2017.

[165] L. Testai and V. Calderone, "Nutraceutical value of Citrus flavanones and their implications in cardiovascular disease," Nutrients, vol. 9, no. 5, 2017.

[166] D. Barreca, G. Gattuso, E. Bellocco et al., "Flavanones: Citrus phytochemical with health-promoting properties," BioFactors, vol. 43, no. 4, pp. 495-506, 2017.

[167] R. Pezzani, B. Salehi, S. Vitalini et al., "Synergistic effects of plant derivatives and conventional chemotherapeutic agents: an update on the cancer perspective," Medicina, vol. 55, no. $4,2019$.

[168] A. Santini, G. C. Tenore, and E. Novellino, "Nutraceuticals: a paradigm of proactive medicine," European Journal of Pharmaceutical Sciences, vol. 96, pp. 53-61, 2017.

[169] D. Scuteri, L. A. Morrone, L. Rombola et al., "Aromatherapy and aromatic plants for the treatment of behavioural and psychological symptoms of dementia in patients with alzheimer's disease: clinical evidence and possible mechanisms. Evidence-based complementary and alternative medicine," eCAM, vol. 2017, Article ID 9416305, 8 pages, 2017. 
[170] Y. Yang, Z. Zhang, S. Li, X. Ye, X. Li, and K. He, "Synergy effects of herb extracts: pharmacokinetics and pharmacodynamic basis," Fitoterapia, vol. 92, pp. 133-147, 2014.

[171] A. Niedzwiecki, M. W. Roomi, T. Kalinovsky, and M. Rath, "Anticancer efficacy of polyphenols and their combinations," Nutrients, vol. 8, no. 9, 2016. 